PNL-6559

\title{
Criticality Experiments with
}

Mixed Oxide Fuel Pin Arrays

in Plutonium-Uranium

Nitrate Solution

\author{
R. C. Lloyd \\ G. R. Smolen
}

August 1988

Prepared for the U.S. Department of Energy under Contract DE-AC06-76RLO 1830

Pacific Northwest Laboratory

Operated for the U.S. Department of Energy by Battelle Memorial Institute 


\title{
DISCLAIMER
}

This report was prepared as an account of work sponsored by an agency of the United States Government. Neither the United States Government nor any agency thereof, nor Battelle Memorial Institute, nor any or their employees, makes any warranty, expressed or implied, or assumes any legal liability or responsibility for the accuracy, completeness, or usefulness of any information, apparatus, product, or process disclosed, or represents that its use would not infringe privately owned rights. Reference herein to any specific commercial product, process, or service by trade name, trademark, manufacturer, or otherwise does not necessarily constitute or imply its endorsement, recommendation, or favoring by the United States Government or any agency thereof, or Battelle Memorial Institute. The views and opinions of authors expressed herein do not necessarily state or reflect those of the United States Government or any agency thereof, or Battelle Memorial Institute.

\author{
PACIFIC NORTHWEST LABORATORY \\ operated by \\ BATTELLE MEMORIAL INSTITUTE \\ for the \\ UNITED STATES DEPARTMENT OF ENERGY \\ under Contract DE-AC06-76RLO 1830
}

\section{DO NOT MICROFILM COVER}


CRITICALITY EXPERIMENTS WITH MIXED OXIDE FUEL PIN ARRAYS IN PLUTONIUM-URANIUM NITRATE SOLUTION

R. C. Lloyd

Pacific Northwest Laboratory

and

\author{
G. R. Smolen \\ Oak Ridge National Laboratory
}

August 1988

Prepared for

the U. S. Department of Energy

under Contract DE-AC06-76RLO 1830

Work performed for the Consolidated

Fuel Reprocessing Program and the

Power Reactor and Nuclear Fuel Development

Corporation of Japan under the Joint

Memorandum of Agreement on Criticality

Data Development

Pacific Northwest Laboratory

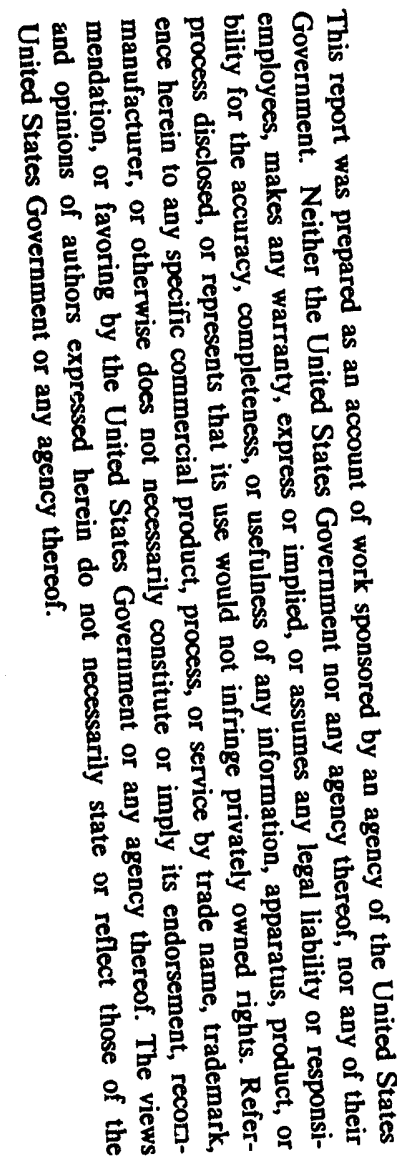

MASTER

Richland, Washington 99352 


\section{SUMMARY}

A series of critical experiments was completed with mixed plutoniumuranium solutions having a $\mathrm{Pu} /(\mathrm{Pu}+U)$ ratio of approximately 0.22 in a boller tube-type lattice assembly. These experiments were conducted as part of the Criticality Data Development Program between the United States Department of Energy (USDOE) and the Power Reactor and Nuclear Fuel Development Corporation (PNC) of Japan. A complete description of the experiments and data are included in this report. The experiments were performed with an array of mixed oxide fuel pins in aqueous plutonium-uranium solutions. The fuel pins were contained in a boller tube-type tank and arranged in a $1.4 \mathrm{~cm}$ square pitch array which resembled cylindrical geometry. One experiment was performed with the fuel pins removed from the vessel. The experiments were performed with a water reflector. The concentration of the solutions in the boiler tube-type tank was varied from 4 to $468 \mathrm{~g}(\mathrm{Pu}+\mathrm{U}) / 1$ iter. The ratio of plutonium to total heavy metal (plutonium plus uranium) was approximately 0.22 for all experiments. 
CONTENTS

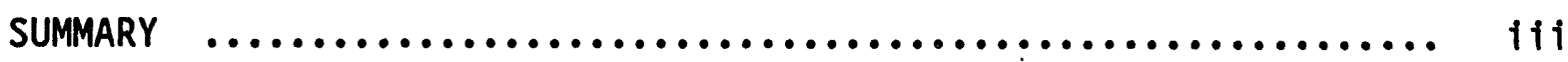

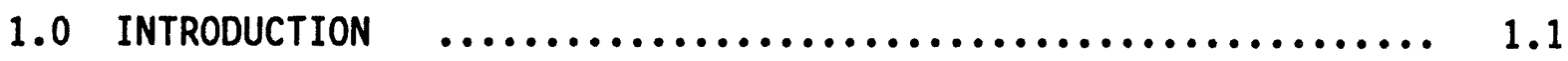

2.0 DESCRIPTION OF EXPERIMENTAL ASSEMBLIES $\ldots \ldots \ldots \ldots \ldots \ldots \ldots . . \ldots, 2.1$

2.1 GENERAL DESCRIPTION OF THE SOLUTION SYSTEM $\ldots \ldots \ldots \ldots \ldots .2 .1$

2.2 CYLINDRICAL VESSEL ASSEMBLY $\ldots \ldots \ldots \ldots \ldots \ldots \ldots \ldots \ldots, 2.4$

2.3 FFTF FUEL PINS $\ldots \ldots \ldots \ldots \ldots \ldots \ldots \ldots \ldots \ldots \ldots \ldots \ldots, 2.17$

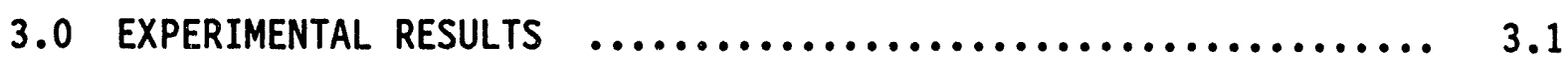

3.1 CRITICALITY MEASUREMENT TECHNIQUE $\ldots \ldots \ldots \ldots \ldots \ldots \ldots . . \ldots \ldots$

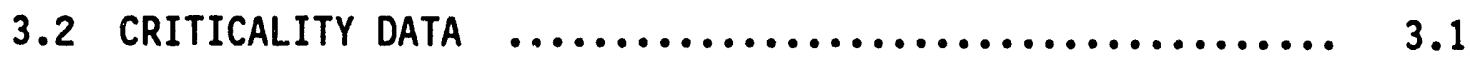

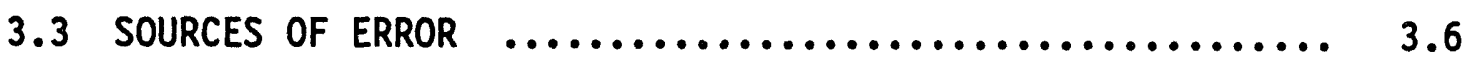

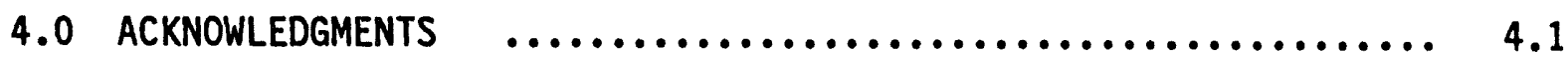

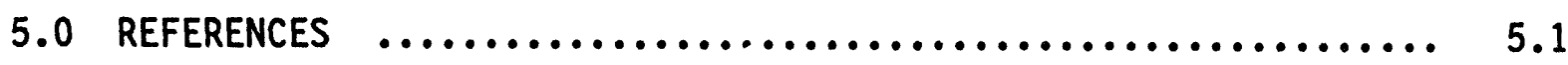

APPENDIX A - A LISTING OF ENGINEERING DRAWINGS FOR THE CYLINDRICAL VESSEL SYSTEM $\ldots \ldots \ldots \ldots \ldots \ldots \ldots$........

APPENDIX B - ENGINEERING DRAWINGS OF THE BOILER TUBE-TYPE TANK ASSEMBLY $\quad \ldots \ldots \ldots \ldots \ldots \ldots \ldots \ldots \ldots \ldots$, B. 1

APPENDIX $C$ - LEAST SQUARE FITS OF THE CRITICAL

APPENDIX $D$ - ANALYSIS OF GADOLINIUM CONCENTRATION DATA $\ldots \ldots \ldots \ldots$ D. 1

APPENDIX E - CHEMICAL ANALYSIS DATA OF THE IMPURITIES

IN PLUTONIUM-URANIUM NITRATE SOLUTIONS $\ldots \ldots \ldots \ldots \ldots$ E. 1

APPENDIX F - CHEMICAL ANALYSIS DATA OF THE REFLECTOR

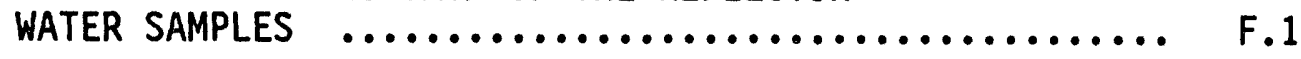




\section{FIGURES}

2.1 Floor Plan Schematic of the Critical Assembly Room ........ 2.2

2.2 Piping Schematic for the Three Experimental Vessels ....... 2.3

2.3 Photograph of the Cylindrical Vessel System $\ldots \ldots \ldots \ldots \ldots \ldots . . \ldots$

2.4 Schematic of Dual Cylinder Tank with Boiler
Tube-Type Tank and Annular Cylinder Mounted $\ldots \ldots \ldots \ldots \ldots \ldots$

2.5 Schematic of Boiler Tube-Type Tank $\ldots \ldots \ldots \ldots \ldots \ldots \ldots \ldots \ldots . \ldots . \ldots$

2.6 Elevation View of Boller Tube-Type Tank ............... 2.8

2.7 Photograph of Polyethylene Spacer $\ldots \ldots \ldots \ldots \ldots \ldots \ldots \ldots \ldots \ldots . \ldots \ldots$

2.8 Photograph of Boiler Tube-Type Tank Inner Assembly ........ 2.11

2.9 Photograph of Polyethylene Spacer Showing

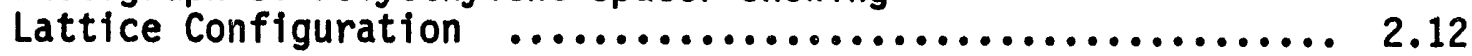

2.10 Photograph of Completed Boiler Tube-Type Tank
Inner Assembly $\ldots \ldots \ldots \ldots \ldots \ldots \ldots \ldots \ldots \ldots \ldots \ldots \ldots \ldots \ldots \ldots \ldots \ldots \ldots$

2.11 Photograph of Completed Boiler Tube-Type Tank ........... 2.15

2.12 Schematic of Boiler Tube-Type Tank Showing As-built Dimensions................................. 2.16

2.13 Simplified Description of Type 3.2 FFTF Fuel Pin........... 2.18

2.14 Photograph of the Boller Tube-Type Tank Showing Insertion of a Mixed Oxide Fuel Pin ............. 2.20

2.15 Photograph of the Boller Tube-Type Tank Loaded with Mixed Oxide Fuel Pins ................... 2.21

3.1 Effect of Plutonium and Uranium Concentration on Critical Height $\ldots \ldots \ldots \ldots \ldots \ldots \ldots \ldots \ldots \ldots \ldots \ldots \ldots \ldots \ldots \ldots \ldots 3 . \ldots$

3.2 Effect of Gadolinium Concentration

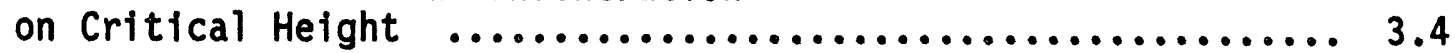

B.1 FTR Fuel Pin Process Tank Assembly ................... B.2

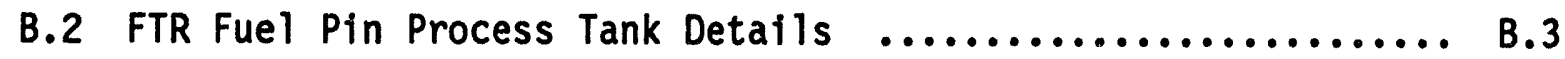

B.3 FTR Fuel Pin Process Tank Details ..................... B.4

B.4 FTR Fuel Pin Process Tank Details .................... B.5

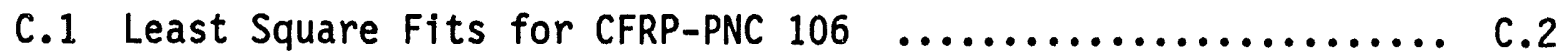




\section{FIGURES (contd)}

C.2 Least Square Fits for CFRP-PNC $106 R \ldots \ldots \ldots \ldots \ldots \ldots \ldots \ldots$ C.3

C.3 Least Square Fits for CFRP-PNC $107 \ldots \ldots \ldots \ldots \ldots \ldots \ldots \ldots$ C.4

C.4 Least Square Fits for CFRP-PNC 109 ................. C.5

C.5 Least Square Fits for CFRP-PNC $110 \ldots \ldots \ldots \ldots \ldots \ldots \ldots \ldots$ C.6

C.6 Least Square Fits for CFRP-PNC $110 R \ldots \ldots \ldots \ldots \ldots \ldots \ldots \ldots$ C.7

C.7 Least Square Fits for CFRP-PNC $111 \ldots \ldots \ldots \ldots \ldots \ldots \ldots \ldots$. .8

C.8 Least Square Fits for CFRP-PNC $112 \ldots \ldots \ldots \ldots \ldots \ldots \ldots \ldots$. .9

C.9 Least Square Fits for CFRP-PNC $113 \ldots \ldots \ldots \ldots \ldots \ldots \ldots \ldots$. c.10

C.10 Least Square Fits for CFRP-PNC $114 \ldots \ldots \ldots \ldots \ldots \ldots \ldots \ldots . \ldots \ldots . . .11$

C.11 Least Square Fits for CFRP-PNC 115 .................... C.12

C.12 Least Square Fits for CFRP-PNC 116 ................... c.13

C.13 Least Square Fits for CFRP-PNC 117 ................... C.14 


\section{$\underline{\text { TABLES }}$}

2.1 Mill Specification Data for Type 304L Stainless Steel Guide Tubes

3.1 Criticality Measurements with Plutonium-Uranium Nitrate Solution in the Boiler Tube-Type Tank $\ldots . . . \ldots . \ldots . . .3 .2$

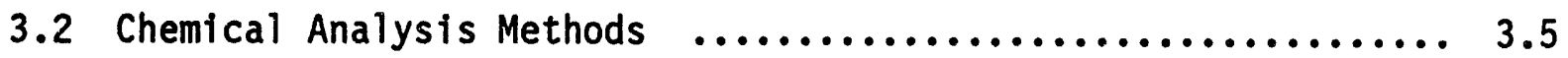

3.3 Chemical Analysis Values for Americium-241 $\ldots \ldots \ldots \ldots \ldots \ldots . . . .6$

3.4 Isotopic Analysis Values of Plutonium and Uranium $\ldots \ldots \ldots \ldots . .3$

3.5 Information on Temperature, Reflector Level, and

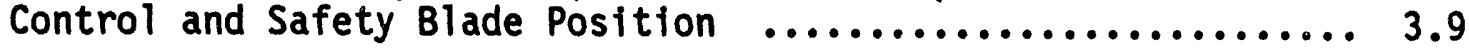

3.6 Estimate of Measurement Uncertainties $\ldots \ldots \ldots \ldots \ldots \ldots \ldots \ldots . . .10$

D.1 Analysis of Gadolinium Concentrations Based on ICP and Loss on Ignition Estimates of Fraction of Gadolinium in Gadolinium Nitrate Powder ................ 0.3

D.2 Analytical Data for Concentrated Gadolinium Solutions ....... 0.4

D.3 Analysis of Gadolinium Concentrations Based on Analytical Results of Concentrated Solutions ............... D.4

D.4 Recovery Data for ICP Analysis ........................ D.4

D.5 Analysis Results of Gadolinium Concentrations

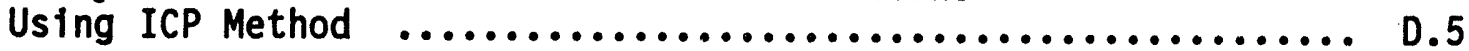

D.6 Summary of Gadolinfum Concentration Evaluations ............. D.5

E.1 Inductively Coupled Plasma Spectroscopy

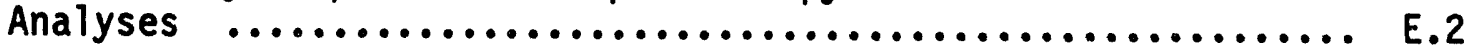

F.1 Water Sample Analyses of the Reflector Water $\ldots . \ldots . \ldots \ldots \ldots$ F.2 
CRITICALITY EXPERIMENTS WITH MIXED OXIDE FUEL

PIN ARRAYS IN PLUTONIUM-URANIUM NITRATE SOLUTION

\subsection{INTRODUCTION}

The design and operation of facilities for recycling Fast Breeder Reactor (FBR) fuels involve criticality conditions which are much different from those encountered in the light water reactor fuel cycle. Conditions are encountered in plant operations with fissionable materials that involve complex equipment shapes, high plutonium content in solution with uranium, and neutron absorbing materials that affect criticality. Experimental criticality data are required for validation of the calculations and nuclear data used in facility design, operational procedures and related licensing activities to ensure freedom from criticality accidents.

In August 1983 the U. S. Department of Energy (DOE) and the Power Reactor and Nuclear Fuel Development Corporation (PNC) of Japan entered into an agreement to study such nuclear criticality aspects as they related to the development of FBR fuel recycling technology. This arrangement was developed through the DOE and PNC Agreement in the Field of Liquid Metal-Cooled Fast Breeder Reactors. Prior to this Joint Memorandum of Agreement (MOA) for Nuclear Criticality Data Development Program, DOE had initiated an experimental program at the DOE Hanford Critical Mass Laboratory to provide basic criticality data on plutonium-uranium systems in support of the U. S. Liquid Metal Fast Breeder Reactor Program. Under this MOA, PNC has promoted and enlarged the DOE Program to cover areas of mutual interest.

Some computer codes for criticality calculations have been developed and applied to FBR fuel cycle facility designs. Application of these codes, however, and the associated cross-section 1ibraries, result in uncertainties on the particular conditions for FBR fuel and need further verification based on actual critical experimental data. Therefore, experimental data are needed which will allow verification of codes and cross-section data to minimize the uncertainties so that facility safety, efficiency, and 
reliability can be enhanced. The verification of criticality evaluation methods is the subject of regulatory licensing activity. These data have application whenever mixtures of plutonium and uranium exist, such as in the head-end dissolution process of a fuel reprocessing plant and wherever heterogeneous systems exist.

This report contains a description of the criticality experiments and the data from the experiments. The experiments were conducted with mixed plutonium-uranium solutions at a $\mathrm{Pu} /(\mathrm{Pu}+\mathrm{U})$ ratio of approximately 0.22 . The experiments were performed in the boiler tube-type lattice assembly which contained an array of mixed oxide fuel pins. The measurements were made with a water reflector. The concentration of the solution in the boiler tubetype tank was varied from 4 to $468 \mathrm{~g}(\mathrm{Pu}+\mathrm{U}) / 1$ iter. Experiments were also performed with gadolinium added to the solution to determine its effectiveness as a neutron poison in a mixed oxide fuel pin array. 


\subsection{DESCRIPTION OF EXPERIMENTAL ASSEMBLIES}

This section includes the general description of the experimental assemblies used in obtaining the criticality data for this report.

\subsection{GENERAL DESCRIPTION OF THE SOLUTION SYSTEM}

An existing experimental system, previously used for solution experiments at the Critical Mass Laboratory, was used for conducting the measurements and providing the data for this report. The solution system is located in the critical assembly room. The addition of solution to the experimental vessel is remotely made from the control room. The layout of equipment in the critical assembly room is shown in Figure 2.1 .

The critical assembly room is 10.67 meters square and has a celling height of 6.4 meters. The side walls are composed of 1.52 meters thick concrete. The concrete celling and floor are each 0.61 meters thick.

The containment hood (Hood 1) was located 1.83 meters from the north wall of the room. The west side of the hood, which faces the wall containing the DS and DM tanks was located 1.52 meters from that wall. The cylindrical vessel assembly positioned south of Hood 1 will be discussed in Section 2.2.

A schematic showing the piping connections between the three experimental vessels is shown in Figure 2.2. This piping arrangement allows critical experiments to be conducted with the same solution in each of three vessels without changing vessels, when desired. The boiler tube-type vessel was used in this series of experiments.

The fill, dump and manometer lines einter the bottom of the vessel through the dump valve system. The dump valve and lines are designed to drain the fissile solution even if the addition were continued. The vessel is connected to the dump valve pedestal by a Marmon flange connection which provides a leak tight connection. 


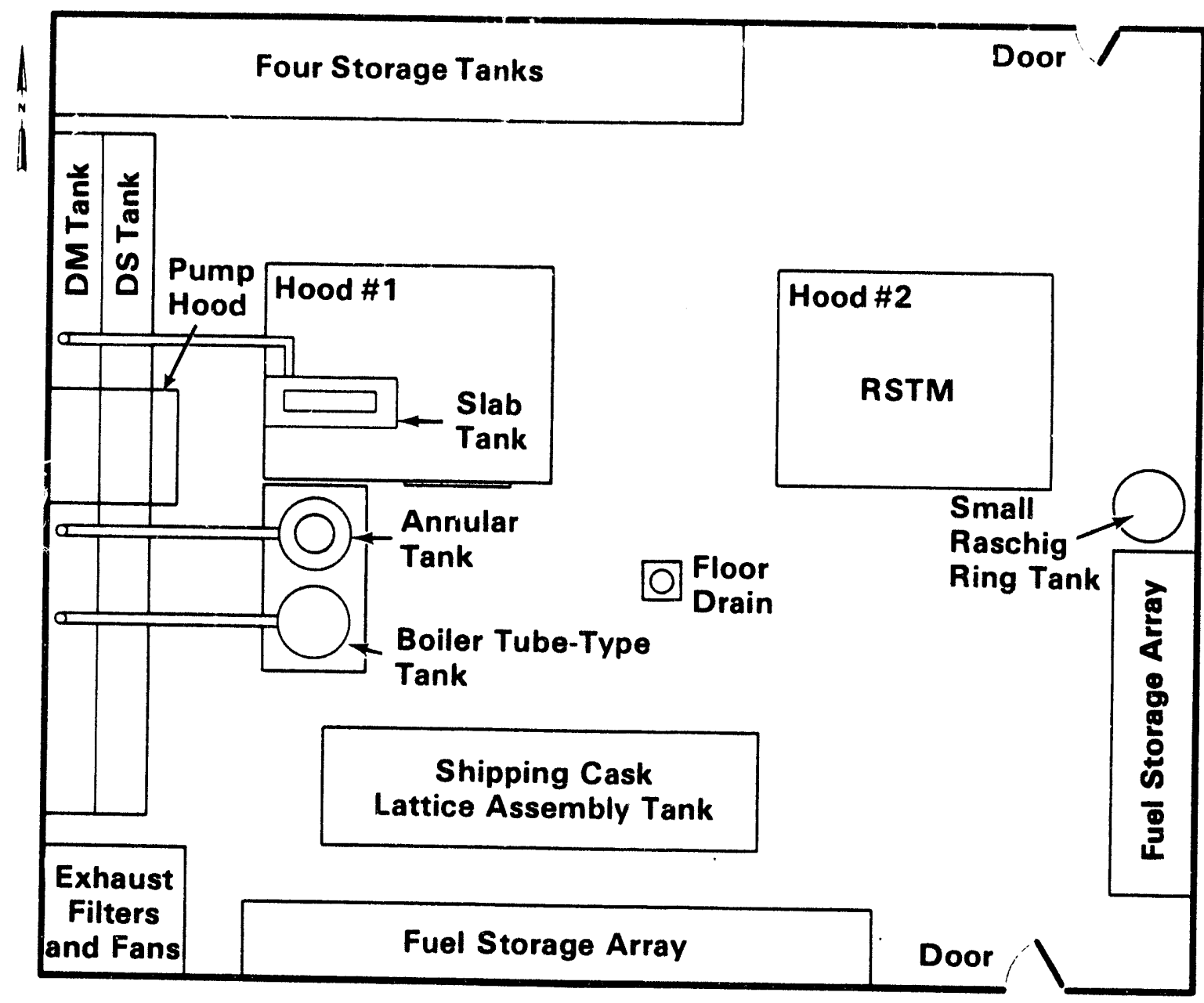

FIGURE 2.1 Floor Plan Schematic of the Critical Assembly Room 


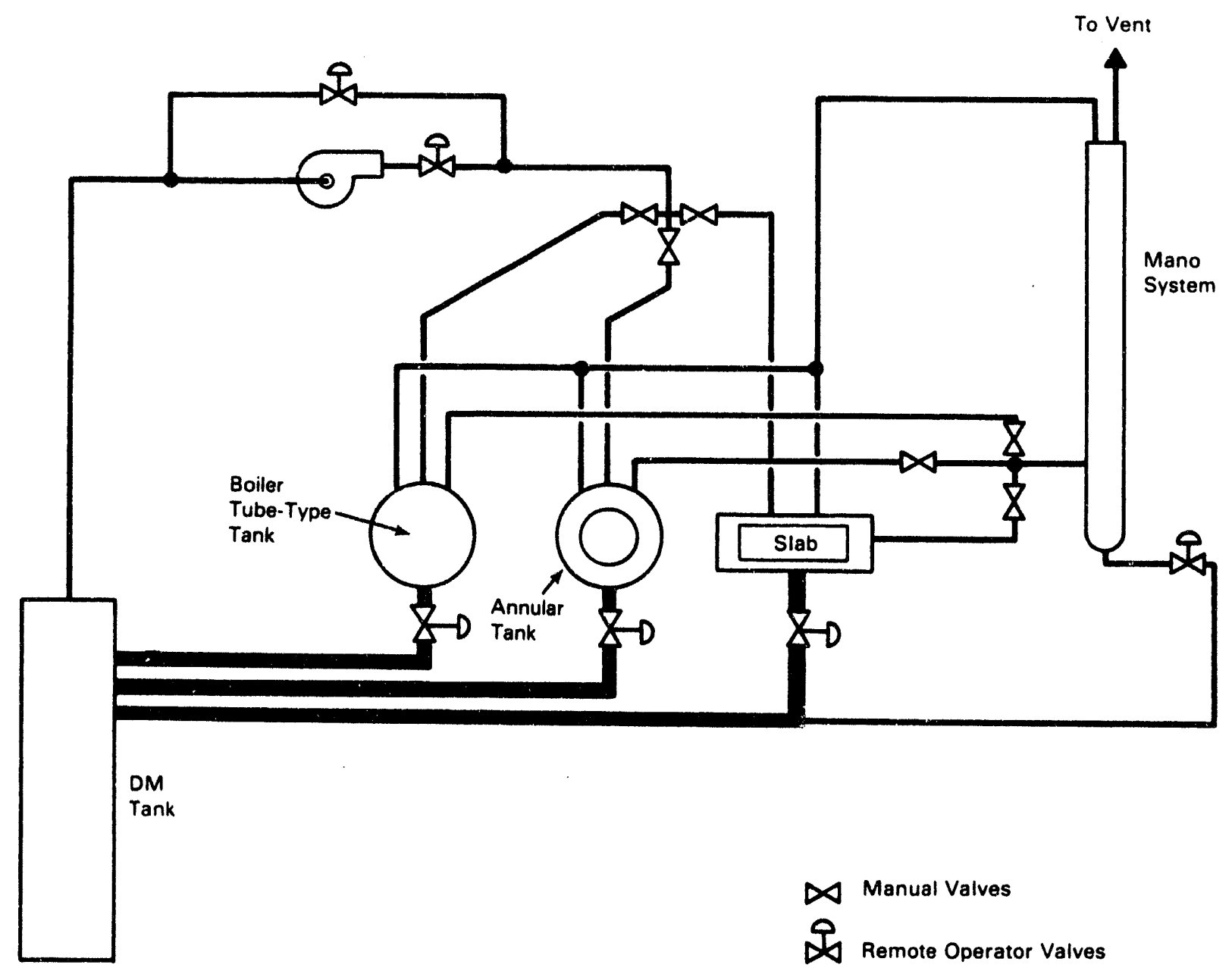

FIGURE 2.2 Piping Schematic for the Three Experimental Vessels 


\subsection{CYLINDRICAL VESSEL ASSEMBLY}

A photograph of the cylindrical vessel system is shown in Figure 2.3. This system contains two cylindrical vessels. The vessel used for the experiments discussed in this report was a boiler tube-type tank and it was located on the left side of the system. The control and safety blade mechanisms were mounted above the vessel and can be seen in the figure. The reflector tank serves to contain water for the water-reflected experiments. Windows of polycarbonate (Lexan) were installed on the front for access to the experimental vessels and for visual inspection. The reflector tank was fabricated of carbon steel. A schematic of the experimental vessel arrangement giving dimensions is shown in Figure 2.4 .

A boiler tube-type tank was fabricated to provide a fixed array of guide tubes. During critical experiments, 996 Type 3.2 Fast Flux Test Facility (FFTF) fuel pins were placed inside the tubes, and the tubes were surrounded by various solutions. A schematic of the vessel is shown in Figure 2.5. The vessel has an outside diameter of $53.188 \mathrm{~cm}$. The wall thickness of the vessel is $0.091 \mathrm{~cm}$. This particular design of the vessel was necessary in. order to isolate the fuel pins from plutonium-bearing solutions. The design of the vessel incorporated a means of attaching the guide tubes to the top plate in a manner that did not warp the plate. The tubes were sealed by $0.635 \mathrm{~cm}$ long plugs laser welded into the ends of the tubes. The other end of the tube was flared and mechanically sealed with a screw-type compression fitting. Only the mechanically sealed end of the tubes were attached to the top plate to prevent bowing of the tubes as a result of differential thermal expansion. The thickness of the top plate is $1.930 \mathrm{~cm}$. An elevation view of the boiler tube-type tank is shown in Figure 2.6 .

The vessel also included a middle lattice plate and a polyethylene spacer to maintain a uniform spacing between tubes throughout the vessel. The diameter and thickness of the middle lattice plate is 52.426 and $0.478 \mathrm{~cm}$, respectively. The diameter of the holes drilled in the plate for the guide tubes is $0.675 \pm 0.004 \mathrm{~cm}$. 


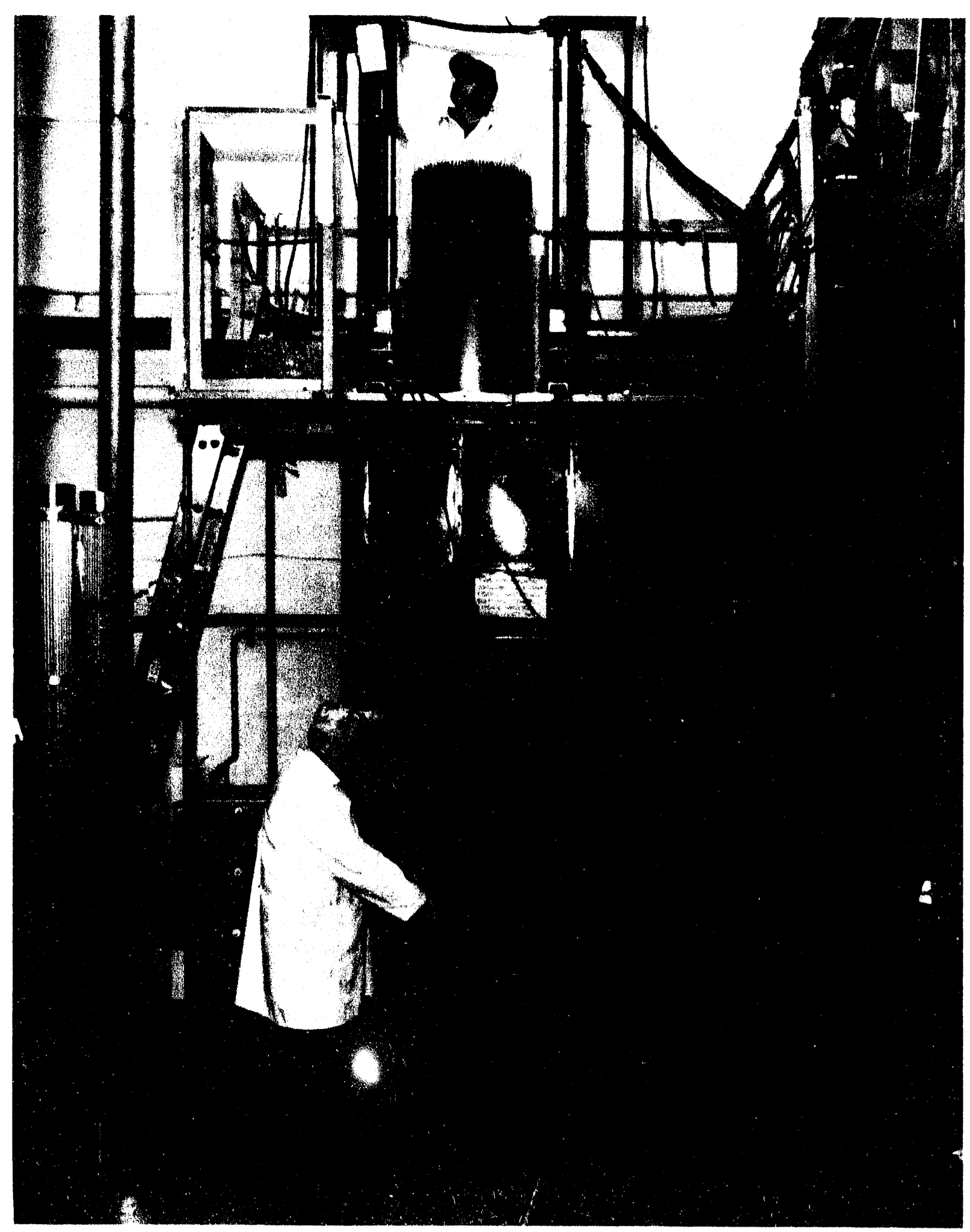

FIGURE 2.3 Photograph of the Cylindrical Vessel System 


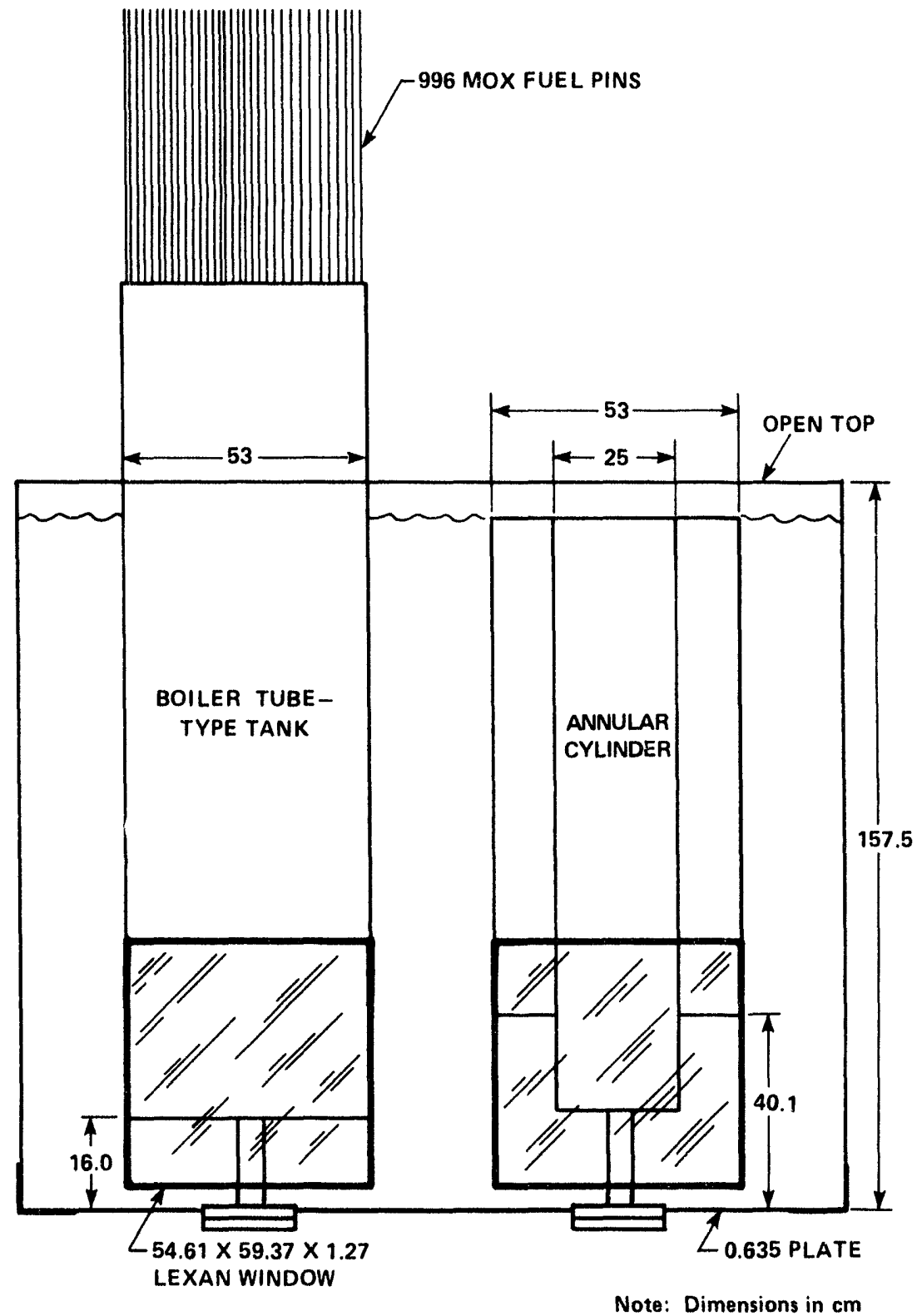

FIGURE 2.4 Schematic of Dual Cylinder Tank with Boiler Tube-Type Tank and Annular Cylinder Mounted 
ORNL-DWG 85-12211R

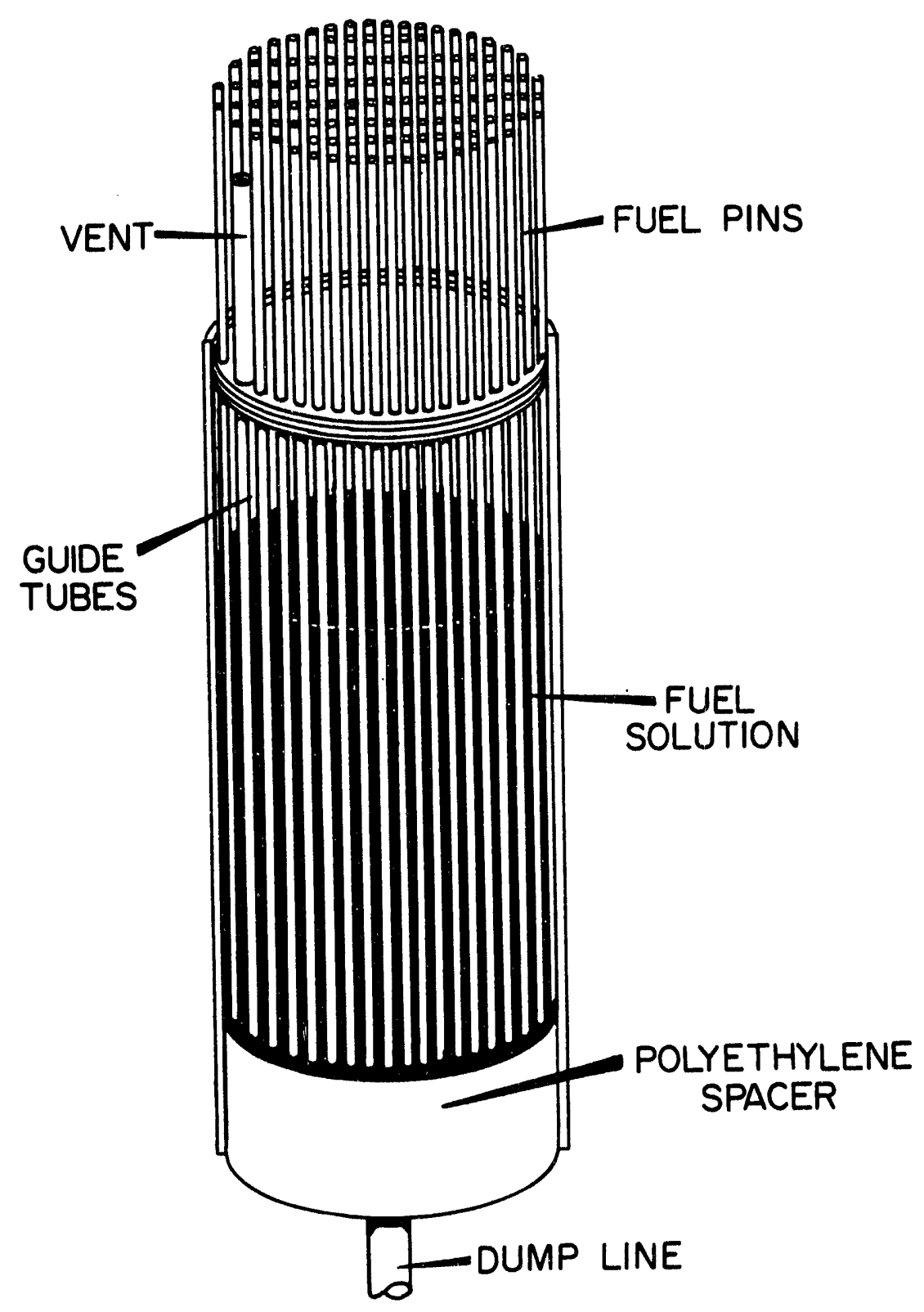

FIGURE 2.5 Schematic of Boiler Tube-Type Tank 


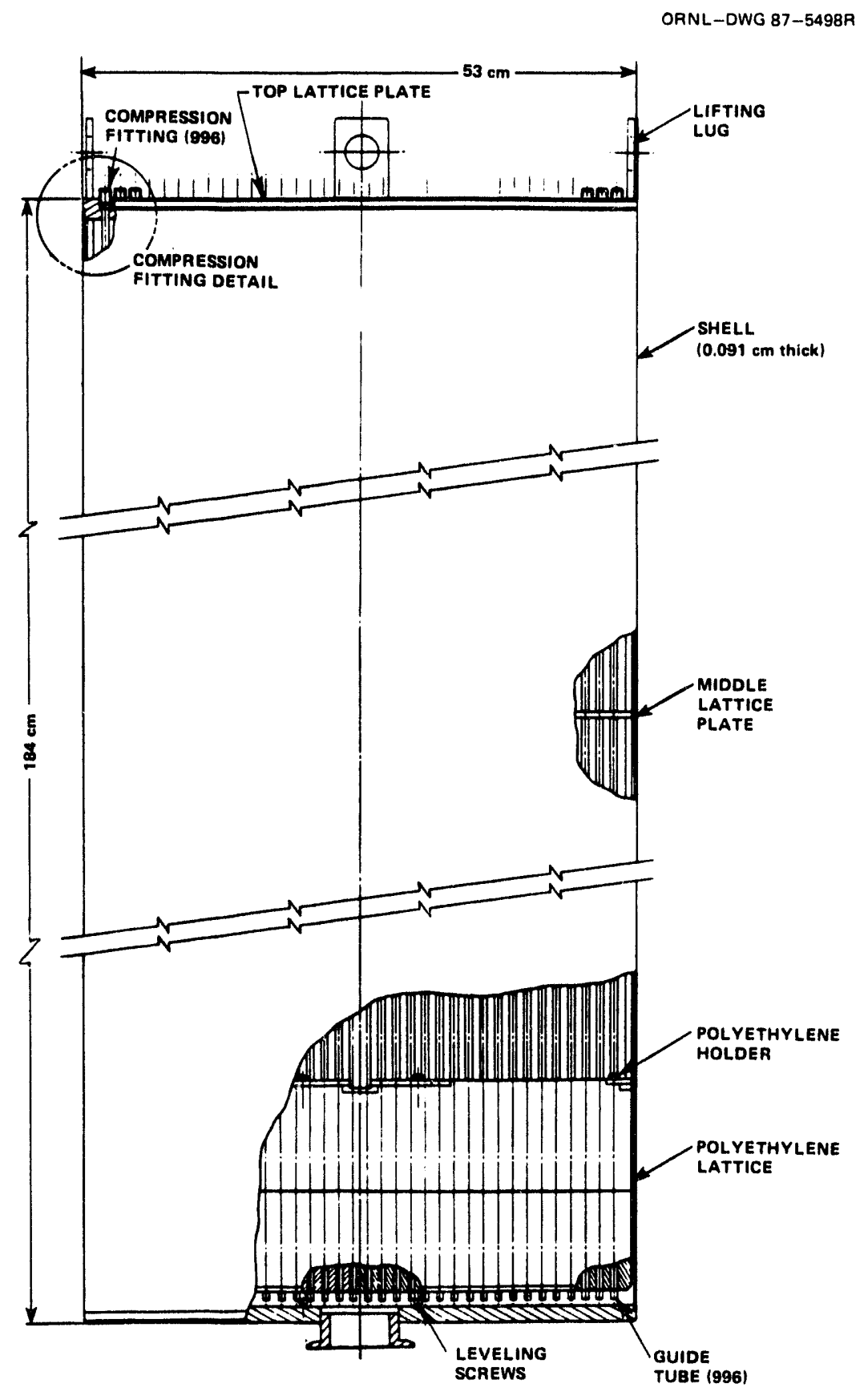

FIGURE 2.6 Elevation View of Boiler Tube-Type Tank 
The polyethylene spacer that was placed at the bottom of the vessel, in the region below the mixed oxide (MOX) fuel, serves to effectively exclude fissile solution from this region. Therefore, neutron multiplication occurs only in the region of interest (i.e., where the MOX is surrounded by fissile solution). The diameter of the 996 holes in the polyethylene spacer is 0.701 $\neq 0.0076 \mathrm{~cm}$. The diameter and height of the spacer is 51.511 and $21.184 \mathrm{~cm}$, respectively. Figure 2.7 is a photograph of the polyethylene spacer which shows that the spacer was fabricated from three separate pieces of polyethylene that were held together by tie bolts. The four pairs of tie bolts were secured to the four spacer holders. The middle lattice plate and the polyethylene spacer were suspended inside the vessel by four rectangular bars (cross sectional dimensions are 0.635 by $1.905 \mathrm{~cm}$ ). In Figure 2.8, the photograph shows the inner assembly and guide tubes used in as-built dimension measurements. The portion of the assembly where the MOX was located, between the middle lattice plate and the spacer, is indicated.

The vessel was designed so that the bottom of MOX fuei would be at the same elevation as the upper surface of the polyethylene spacer. Based on measurements made after fabrication of the inner assembly, the top surface of the spacer was estimated to be $0.028 \mathrm{~cm}$ above the bottom of the MOX fuel. However, since the uncertainty in these measurements is $0.127 \mathrm{~cm}$, the levels should be considered to have the same elevation. Also, the bottom of the guide tube plugs was found to extend beyond the spacer by $0.04=0.15 \mathrm{~cm}$. The uncertainties associated with the above two measured values are large because these measurements were not made directly. Instead, these values were determined by taking the difference between a series of measurements taken inside and outside selected guide tubes. The spacer is $0.922 \mathrm{~cm}$ above the inside surface of the bottom plate of the vessel to allow for filling and draining. Four set screws were inserted into the spacer to assure that the vessel could be drained.

An analysis of the top plate, middle lattice plate and polyethylene spacer true position measurement data found that the holes had a square pitch of $1.400 \neq 0.003 \mathrm{~cm}$. In Figure 2.9 , the photograph is a view under the polyethylene spacer showing the plug-end of the 996 guide tubes and the 


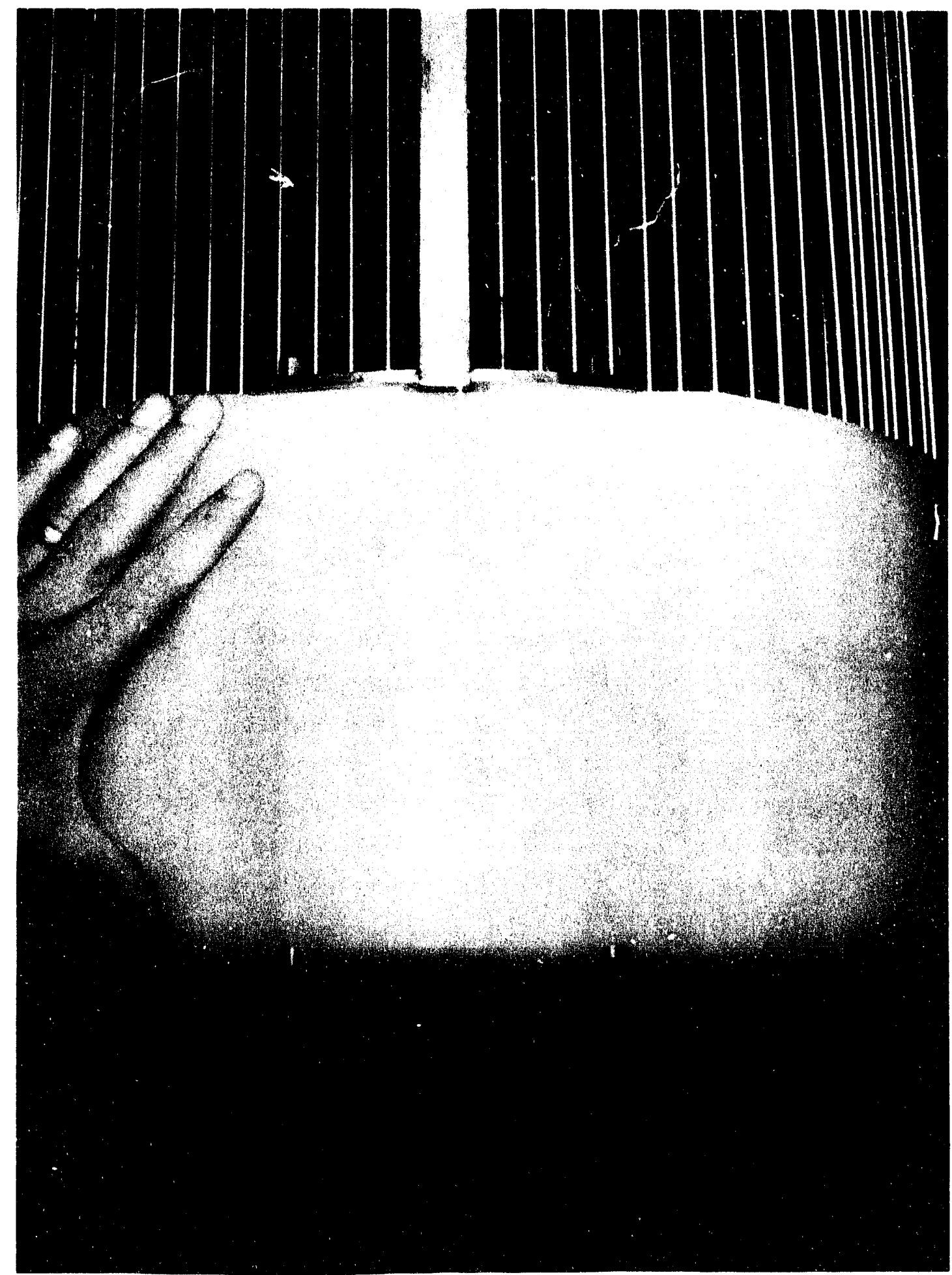

FIGURE 2.7 Photograph of Polyethylene Spacer 


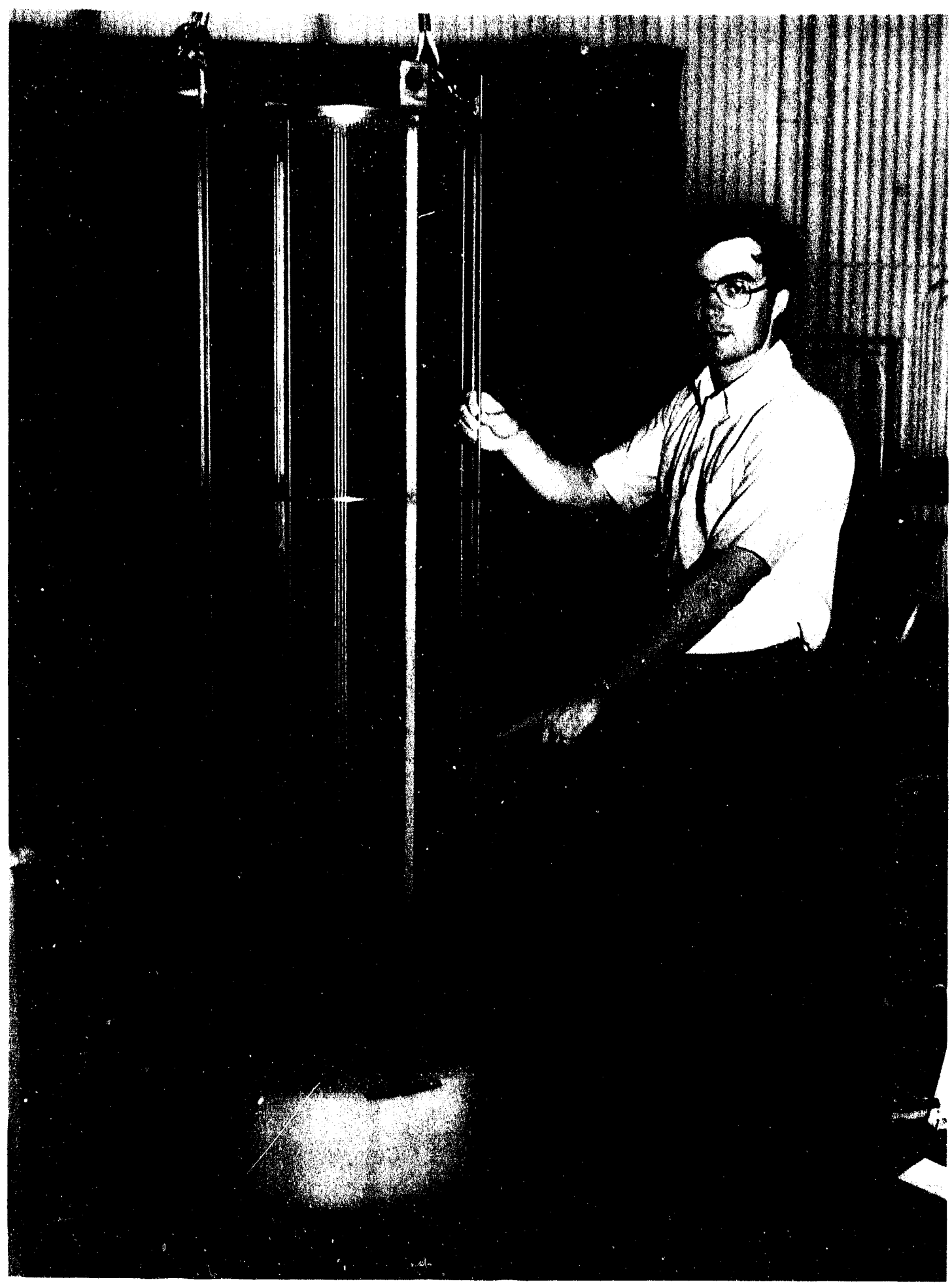

FIGURE 2.8 Photograph of Boiler Tube-Type Tank Inner Assembly 


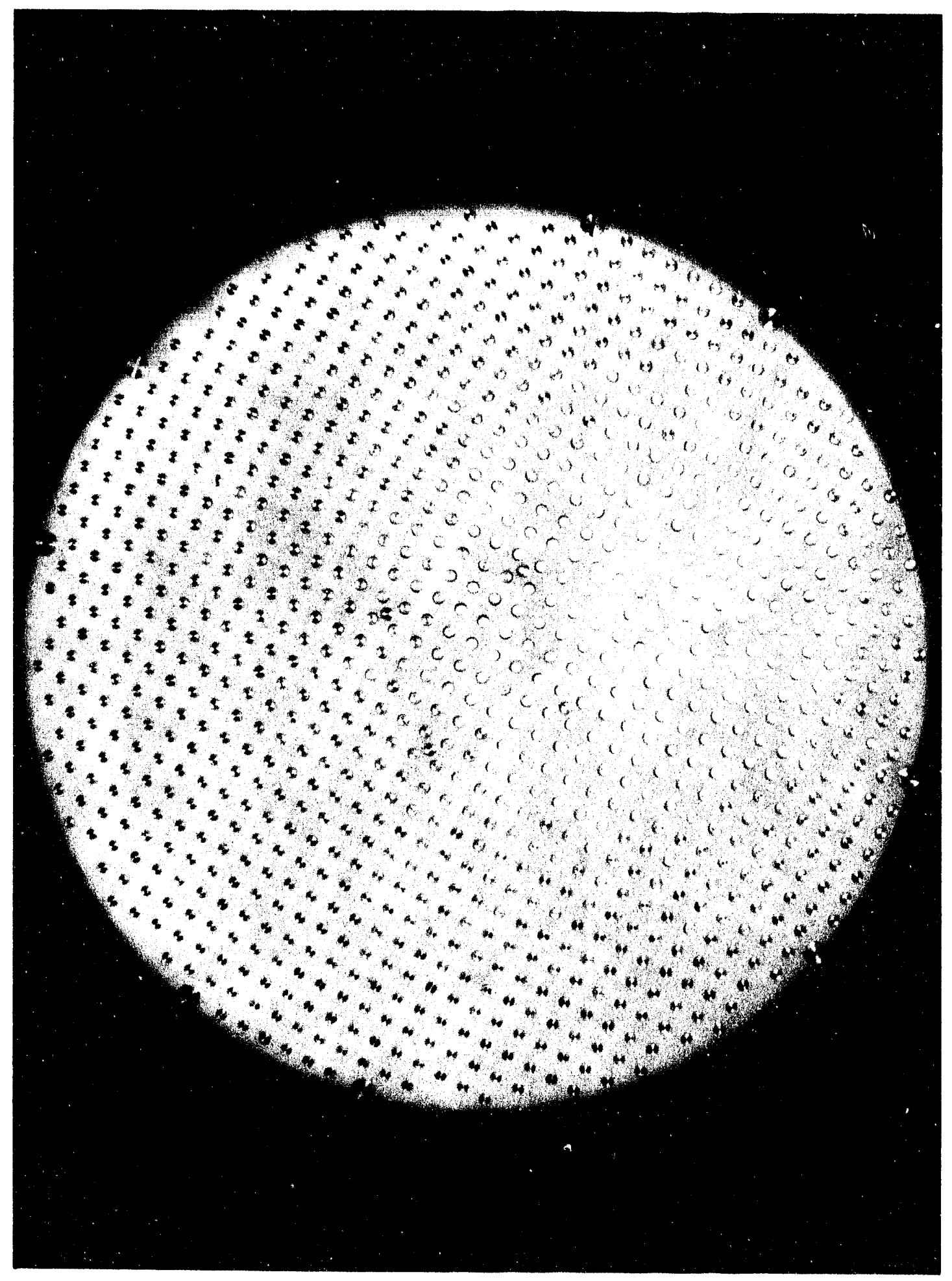

FIGURE 2.9 Photograph of Polyethylene Spacer Showing Lattice Configuration 
geometrical arrangement of the tubes. Also shown are the four leveling screws and the eight tie bolts. The completed inner assembly is shown in Figure 2.10, and the completed boiler tube-type tank is shown in Figure 2.11 . The schematic of the vessel 11 lustrated in Figure 2.12 summarizes all of the vital as-built dimensions.

All materials used in the fabrication of the boiler tube-tyre tank were certified Type 304L stainless steel, except for the compression fittings (Type 17-4PH stainless steel) and the polyethylene spacer. The spacer was fabricated from blocks of Number 213 "pure polyethylene" supplied by Reactor Experiments, Inc. The listed density for this material is $0.9 \mathrm{~g} / \mathrm{cm}^{3}$. Due to the importance of the material composition of the guide tubes, the data from the mill specifications are provided in Table 2.1. The outside diameter of the tubes is $0.6462 \pm 0.0028 \mathrm{~cm}$ and the inside diameter is $0.6083 \pm 0.0013 \mathrm{~cm}$.

The control and safety blades were external to the vessel and were withdrawn during the neutron flux measurements taken in the course of the critical approach. The experiments with the boiler tube-type tank were conducted with the reflector tank containing water. The reflector tank was filled to a level $56 \mathrm{~cm}$ below the top of the boiler tube-type tank. The distance between the boller tube-type tank bottom (outside surface) and the bottom of the reflector tank (inside surface) is $16.0 \pm 0.2 \mathrm{~cm}$.

Engineering drawings were provided in PNL-5768 (Lloyd 1986) for the cylindrical vessel system; these contain detailed dimensions used in fabrication. A listing of the engineering drawings is provided in Appendix $A$ for cylindrical vessel system.

Engineering drawings for the boiler tube-type tank assembly are provided in Appendix $B$. 


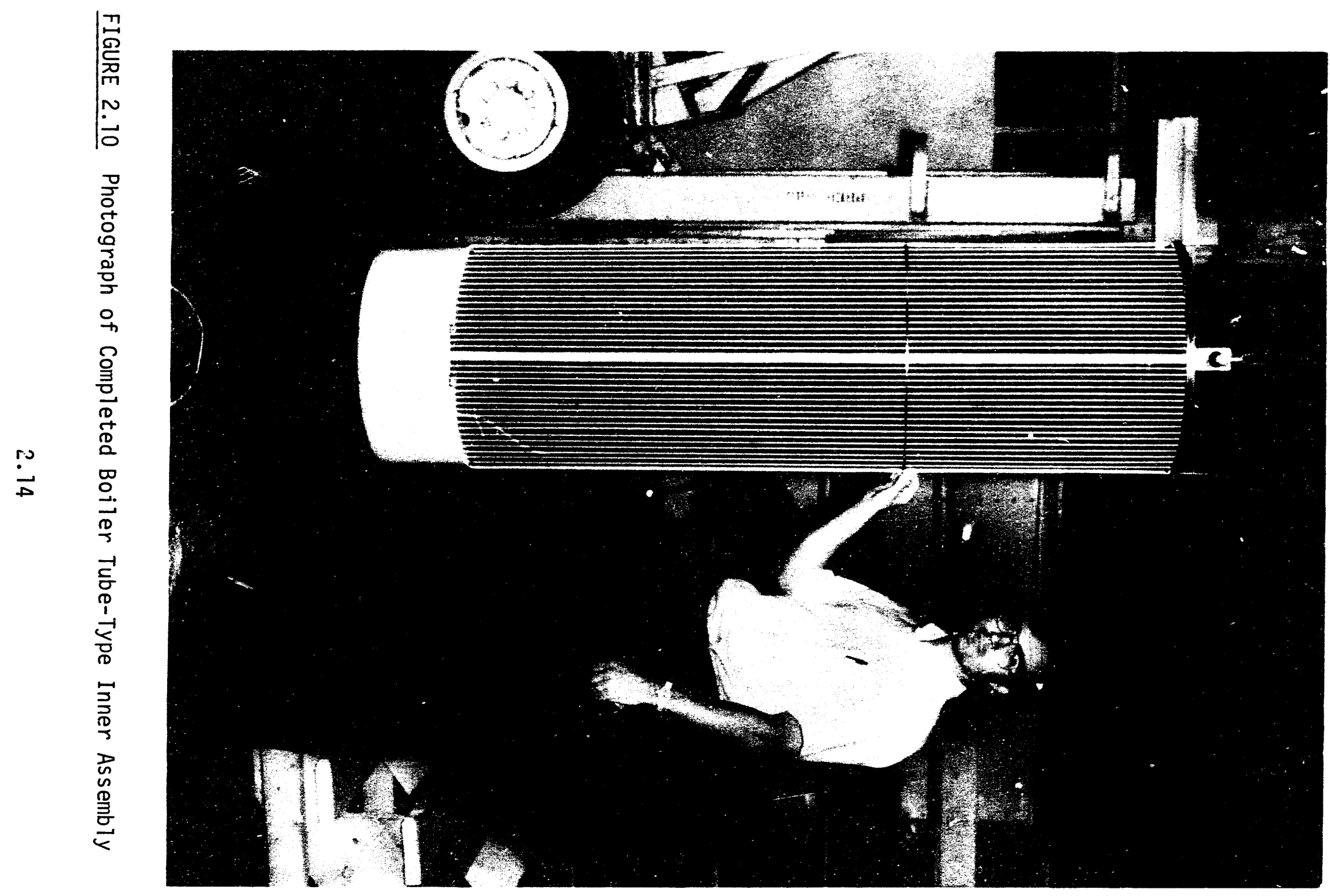




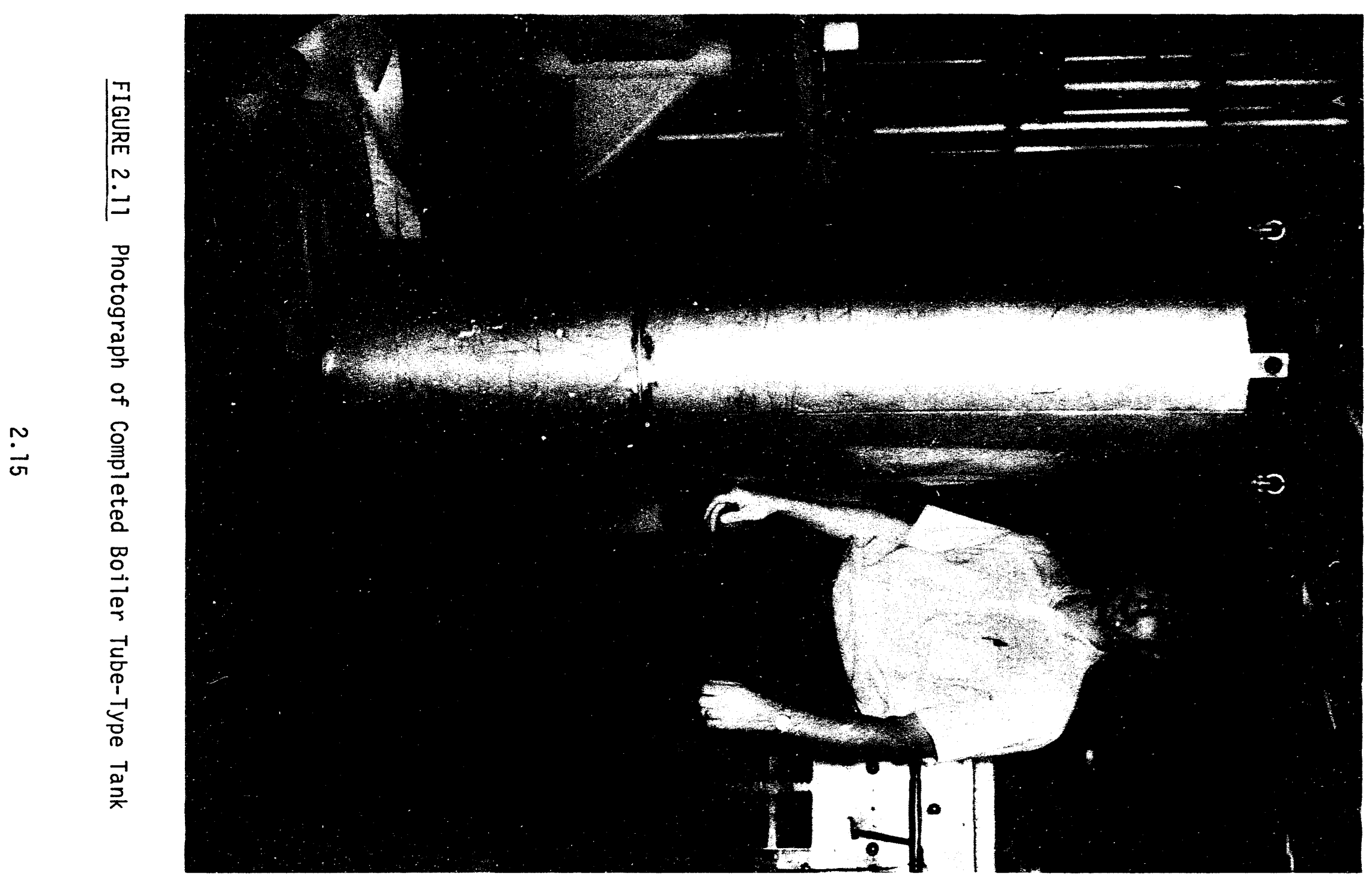




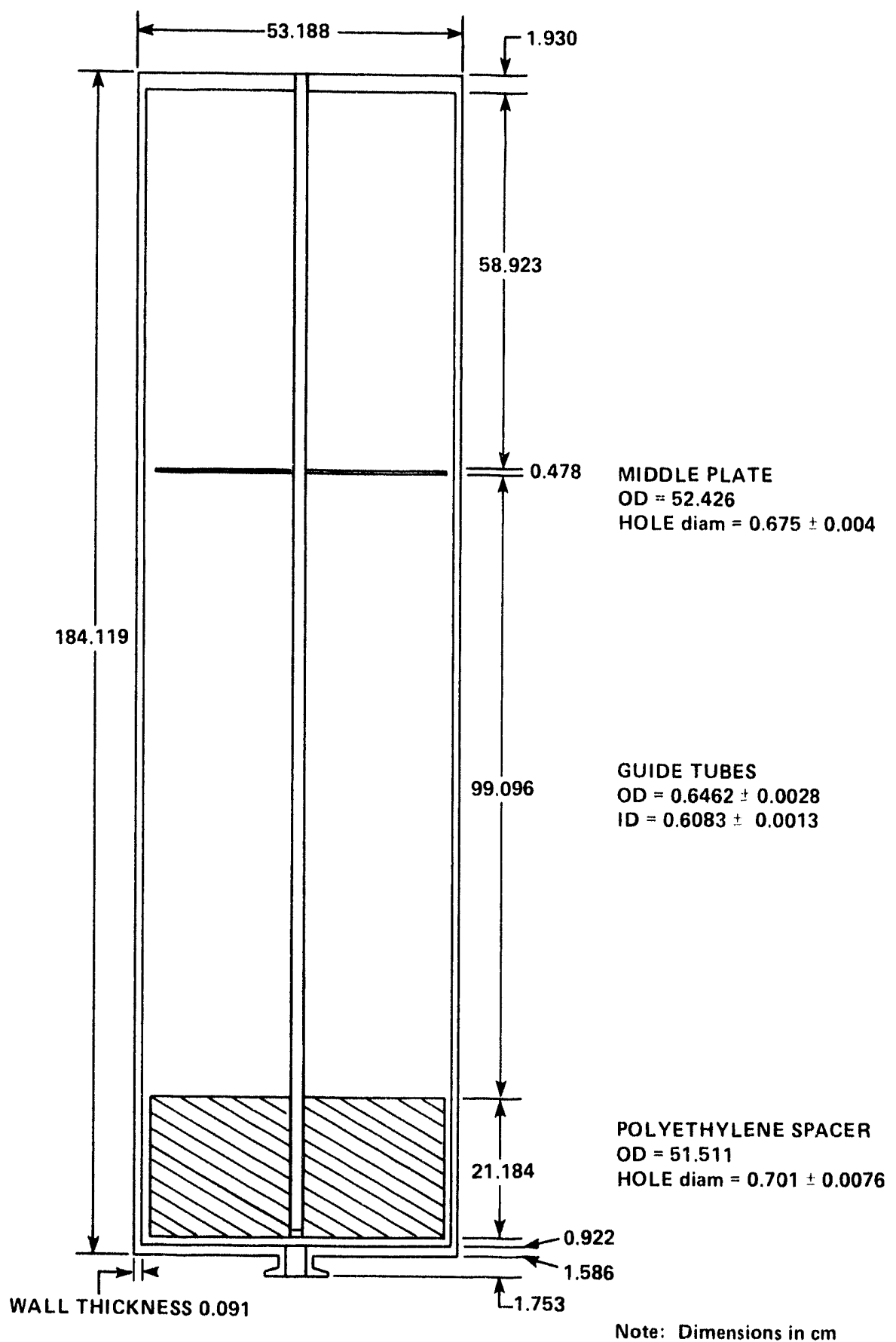

FIGURE 2.12 Schematic of Boiler Tube-Type Tank Showing As-built Dimensions 
TABLE 2.1 Mill Specification Data for Type

304L Stainless Steel Guide Tubes

$\begin{array}{ll}\text { Element } & \text { Wt\% } \\ \mathrm{Fe} & 69.208 \\ \mathrm{Cr} & \mathrm{a}) \\ \mathrm{Ni} & 18.33 \\ \text { Mn } & 9.33 \\ \mathrm{Si} & 1.54 \\ \text { Mo } & 0.47 \\ \mathrm{Cu} & 0.31 \\ \mathrm{C} & 0.29 \\ \mathrm{Co} & 0.24 \\ \mathrm{~N} & 0.19 \\ \mathrm{P} & 0.060 \\ \mathrm{~S} & 0.027 \\ & 0.005\end{array}$

(a) Balance of data to equal $100 \mathrm{wt} \%$.

\subsection{FFTF FUEL PINS}

The critical experiments were conducted with Type 3.2 FFTF mixed oxide fuel pins. These fuel pins were used in other critical experiments that have been performed at the PNL-CML (Bierman 1986, Bierman 1979, and Durst 1980). The fuel pins were referred to as Fast Test Reactor (FTR) pins in these reports. The Type 3.2 FFTF fuel pins contain 19.78 wt\% plutonium. The isotopic and density data for these paiticular fuel pins are given in Figure 2.13. These data are based on measured data from pellet lots used in fabricating the fuel and are more accurate than the information previously reported (Bierman 1979, Durst 1980, and Primm 1980). The dimensions of the fuel pins are also given in Figure 2.13. The actual MOX fuel region is restricted to a $91.4 \mathrm{~cm}$ length near the bottom of the pins. The remainder of the pin consists of Inconel reflectors, end caps and other hardware. As discussed in the previous section, the elevation of the Mox fuel should be considered equal to the top of the polyethylene spacer of the boiler tubetype tank. 


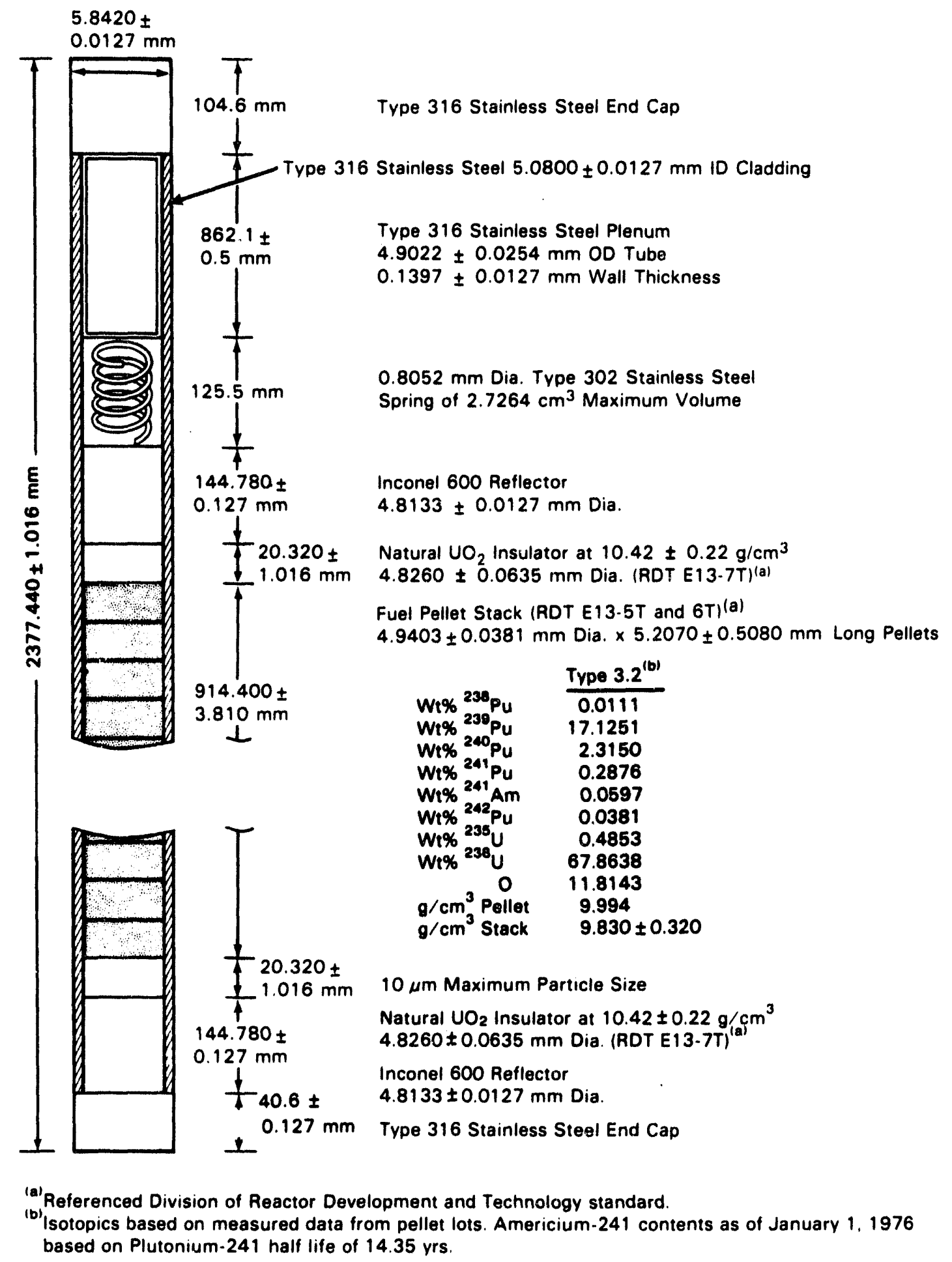

FIGURE 2.13 Simplified Description of Type 3.2 FFTF Fue1 Pin 
Figure 2.14 shows the loading of a fuel pin into the boiler tube-type tank prior to mounting on the experimental assembly. Figure 2.15 shows the boiler tube-type assembly loaded with 996 fuel pins. 


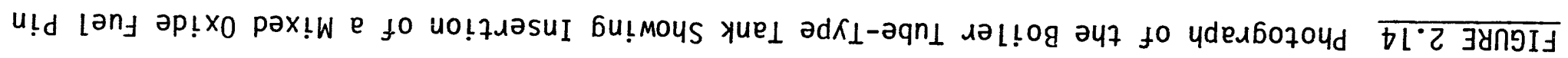

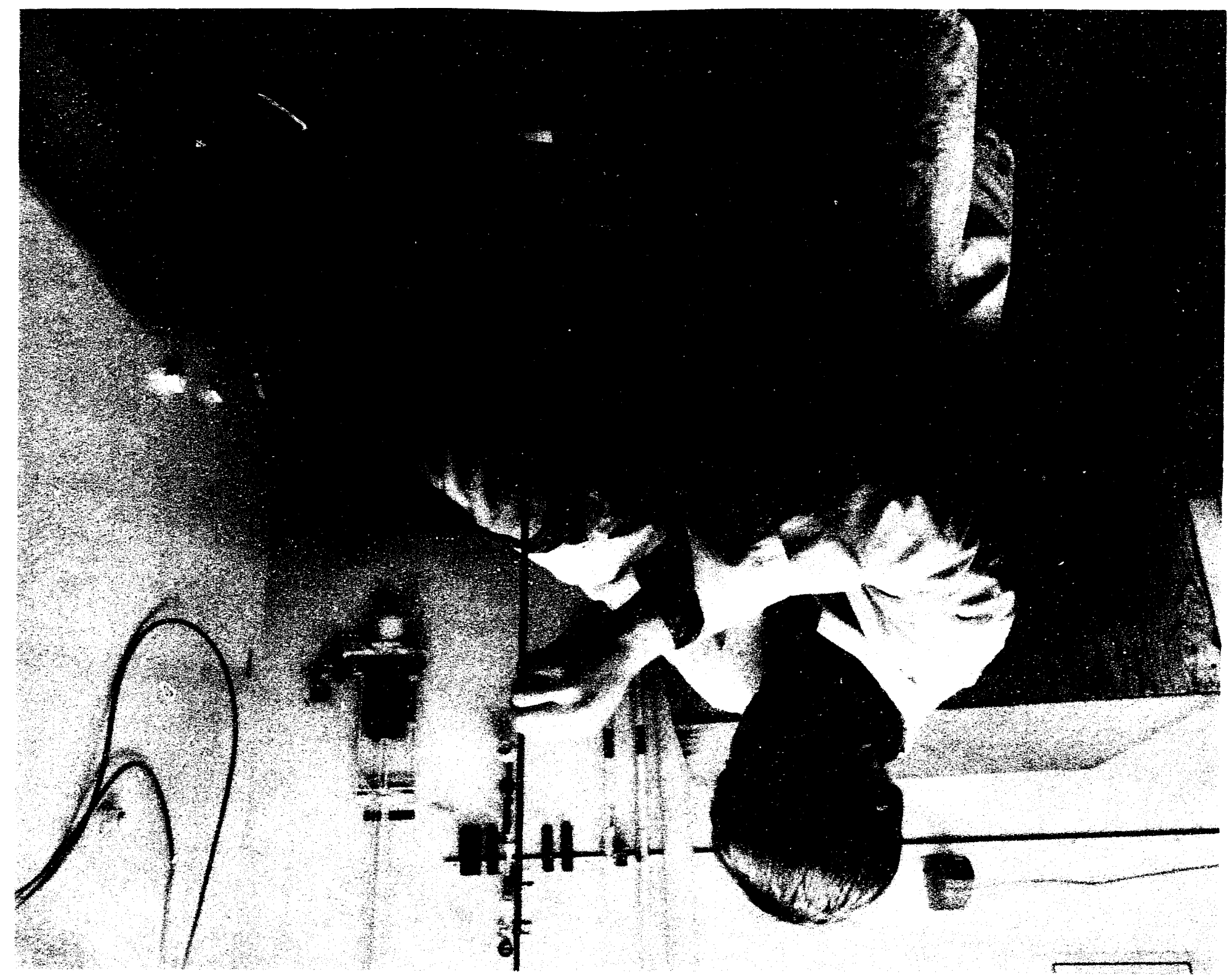




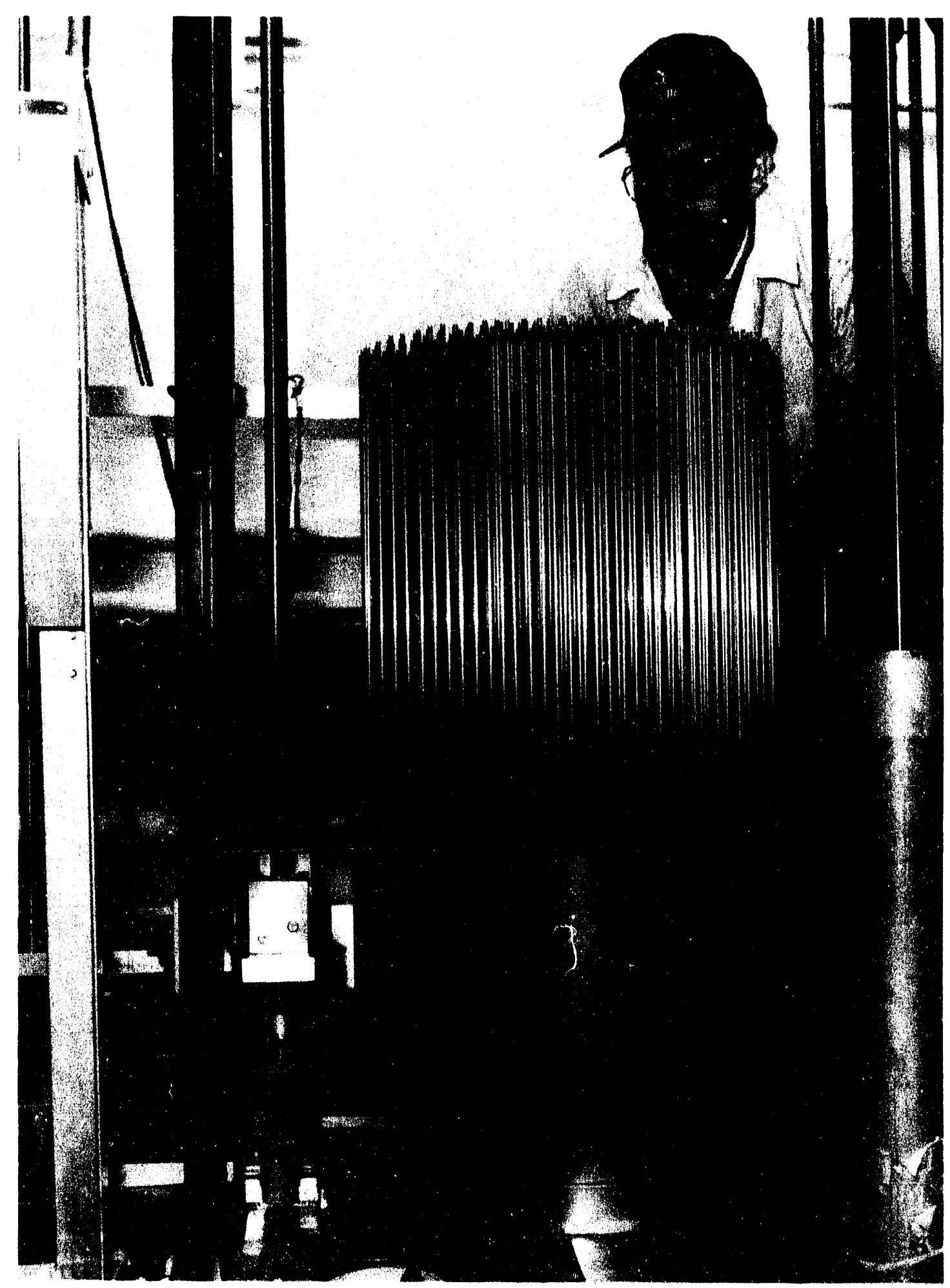

FIGURE 2.15 Photograph of the Boiler Tube-Type Tank Loaded with Mixed Oxide Fuel Pins 


\subsection{EXPERIMENTAL RESULTS}

This section provides the results of the experiments including a description of the measurement techniques involved in obtaining the data.

\subsection{CRITICALITY MEASUREMENT TECHNIQUE}

The critical heights for the experiments reported herein were determined using the critical approach method (Clayton 1985). In this critical approach method, neutron flux measurements are made as the height of solution is incrementally increased. Inverse count rate is plotted versus solution height. At delayed critical condition the neutron count rate approaches infinity so that the inverse count rate approaches zero. By extrapolation of the inverse multiplication curves to zero value, the critical height is determined for the system. The neutron flux is routinely taken on three boron-lined proportional detectors located near the experimental vessel. The data from the three counters extrapolate to essentially identical values for solution height at near critical values. The computer calculated least square fits of the inverse multiplication curves, used in determining the critical value for the solution height in each experimental assembly, are included in Appendix C.

\subsection{CRITICALITY DATA}

The criticality data for this report were obtained between November 1987 and April 1988, when thirteen experiments were completed using the boiler tube-type tank system. The data are summarized in Table 3.1. Figure 3.1 shows a plot of the critical heights determined at various concentrations of the plutonium-uranium nitrate over a range of $\sim 4$ to $468 \mathrm{~g}(\mathrm{Pu}+\mathrm{U}) / 1$ iter in the boller tube-type assembly loaded with the mixed oxide fuel pins. Figure 3.2 shows a plot of the critical heights determined for a concentration of $\sim 464 \mathrm{~g}$ $(\mathrm{Pu}+\mathrm{U}) / 1$ iter for various additions of gadolinium from $\sim 0$ to $2.2 \mathrm{~g} \mathrm{Gd} / 11$ ter. The sample analysis methods and descriptive titles are given in Table 3.2. The critical heights were calculated by a least squares fit to the inverse neutron multiplication data from three neutron detectors (computer printout provided in 
TABLE 3.1 Criticality Measurements with Plutonium-Uraniym

\begin{tabular}{|c|c|c|c|c|c|c|c|c|c|}
\hline $\begin{array}{l}\text { Run } \\
\text { Date }\end{array}$ & $\begin{array}{l}\text { Project } \\
\text { Case } \\
\text { Nunber } \\
\end{array}$ & $\begin{array}{l}\text { CI } \\
\text { Experinent } \\
\text { Number } \\
\end{array}$ & $\begin{array}{l}\text { Sample } \\
\text { Number }\end{array}$ & $\begin{array}{c}\mathrm{Pu} \\
\text { (o/litor) }\end{array}$ & $\begin{array}{c}U \\
\text { (g/liter) }\end{array}$ & $\begin{array}{c}\text { ed } \\
\text { (q/liter) }\end{array}$ & $\begin{array}{c}\text { Density }^{(b)} \\
\left(\mathrm{g} / \mathrm{cm}^{3}\right) \\
\end{array}$ & $\begin{array}{l}\text { Free } \\
\text { Acid } \\
(M) \\
\end{array}$ & $\begin{array}{c}\text { Critical } \\
\text { Hoight } \\
\text { (cm) } \\
\end{array}$ \\
\hline $11 / 64 / 87$ & $51 C$ & 166 & 1230 & 0.88 & 2.7 & 0.0 & 1.0170 & 0.41 & 18.41 \\
\hline $11 / 65 / 87$ & S1CR & $106 R$ & 1230 & 0.88 & 2.7 & 0.0 & 1.0170 & 0.41 & 18.55 \\
\hline $11 / 69 / 87$ & 41 & 107 & 1231 & 73.95 & 254.00 & 1.0 & 1.4833 & 0.57 & 21.34 \\
\hline $11 / 19 / 87$ & 51 & 169 & 1233 & 47.50 & 163.66 & 0.0 & 1.3168 & 0.52 & 20.01 \\
\hline $11 / 24 / 87$ & 52 & 110 & 1234 & 22.03 & . 77.84 & 5.0 & 1.1577 & 0.47 & 18.98 \\
\hline $11 / 25 / 87$ & E2R & I10R & 1234 & 22.63 & 77.84 & 1.0 & 1.1577 & 0.47 & 19.63 \\
\hline $12 / 62 / 87$ & 40 & 111 & 1235 & 108.70 & 363.98 & 0.0 & 1.6784 & 0.86 & 23.87 \\
\hline $12 / 69 / 87$ & 65 & 112 & 1236 & 103.18 & 360.82 & 0.49 & 1.6758 & 0.65 & 30.28 \\
\hline $12 / 11 / 87$ & 68 & 113 & 1237 & 162.23 & 359.69 & 6.98 & 1.6746 & 0.65 & 38.78 \\
\hline $12 / 17 / 87$ & 70 & 114 & 1238 & 102.65 & $35^{\circ} 59$ & 1.47 & 1.6746 & 0.68 & 51.66 \\
\hline $12 / 23 / 87$ & $78 C 1$ & 115 & 1239 & 102.68 & 350.55 & 1.97 & 1.6748 & 6.65 & 73.68 \\
\hline $12 / 31 / 87$ & $78 \mathrm{C2}$ & 116 & 1248 & 103.61 & 362.46 & 2.16 & 1.6796 & 6.65 & 96.27 \\
\hline $04 / 64 / 88$ & --- & 117 & 1263 & 83.30 & 286.57 & 6.6 & 1.5507 & 0.90 & 27.42 \\
\hline
\end{tabular}

(a) Boiler tube-type tank conteined 996 FFT Type 3.2 pins except for experinent 117 where the fuel pins were renoved. The vessel was water roflected.

(b) Density measured at $23^{\circ} \mathrm{C}$

(c) Zero reference is the top of the polyethylene spacer. 


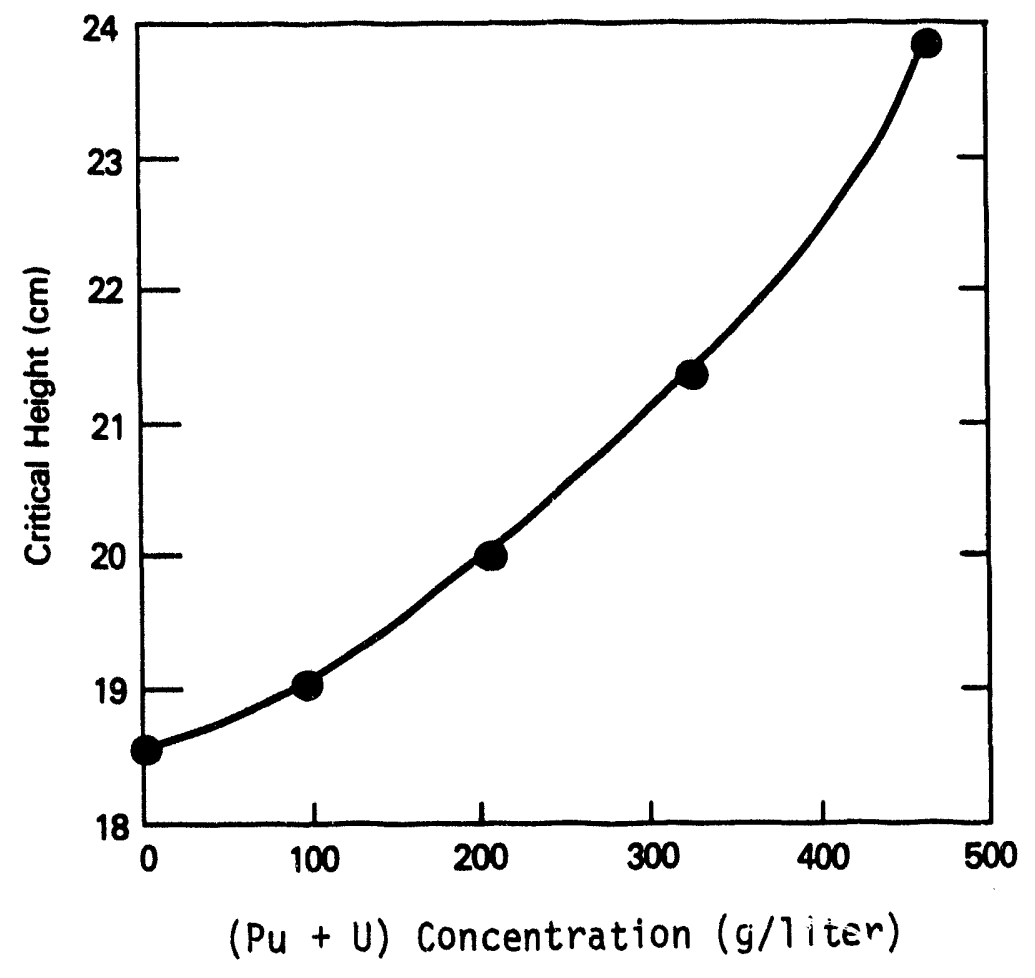

FIGURE 3.1 Effect of Plutonium and Uranium Concentration on Critical Height 


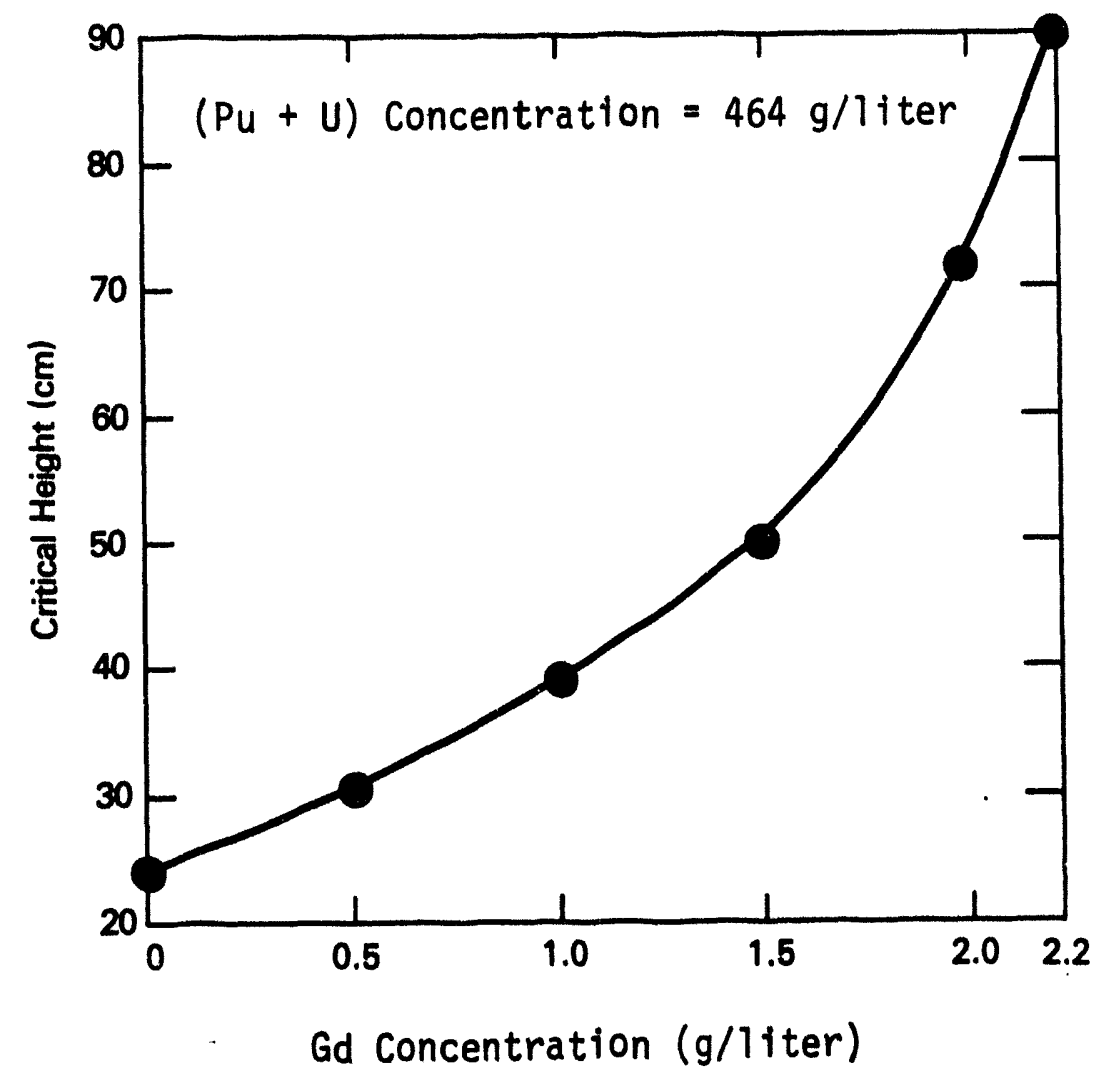

FIGURE 3.2 Effect of Gadolinium Concentration on Critical Height 
TABLE 3.2 Chemical Analys is Methods

\begin{tabular}{|c|c|c|}
\hline Mosaurement & Mathod Title(a) & $\begin{array}{l}\text { Date of } \\
\text { Approval }\end{array}$ \\
\hline Plutoniun & $\begin{array}{l}\text { Plutoniun by Autonated Aaperonetric } \\
\text { Titration. }\end{array}$ & $18 / 18 / 85$ \\
\hline Plutoniun & $\begin{array}{l}\text { Plutoniun Purification by Ion } \\
\text { Exchange. }\end{array}$ & $83 / 11 / 86$ \\
\hline Uraniuv & $\begin{array}{l}\text { Uraniun by Autonatod Potentionotric } \\
\text { Titration. }\end{array}$ & $02 / 05 / 86$ \\
\hline${ }^{241}{ }_{A m}$ & $\begin{array}{l}\text { Americiun-241 by Anion Exchange and } \\
\text { Alpha Analysis. } \\
\text { (46.10) }\end{array}$ & $05 / 14 / 75$ \\
\hline Free Acid & $\begin{array}{l}\text { Dateraination of Free Acid in Uraniun/ } \\
\text { Plutoniun Solutions. (Using an } \\
\text { iaproved oxalate sethod) } \\
\text { (40.22) }\end{array}$ & $12 / 04 / 86$ \\
\hline Density & $\begin{array}{l}\text { Density of Solutions. (Using Mottler/ } \\
\text { Paar Density Moter) } \\
\text { (40.23) }\end{array}$ & $02 / 05 / 86$ \\
\hline Isotopic & $\begin{array}{l}\text { Isotopic Conposition of Plutoniun } \\
\text { and Uranium by Mass Spoctroscopy. }\end{array}$ & $69 / 27 / 78$ \\
\hline Od, Inpurities & ICP Anolysis. (b) & $04 / 01 / 86$ \\
\hline Od, Od Hydrate & ICP Analyois. (c) & $97 / 01 / 87$ \\
\hline
\end{tabular}

Od Hydrate Gravinotric. (PNL MA-597 Vol. 2) 05/38/75

(a) The nuabers in brackets are nethod nuabers for PML $M-597$, Vol 2, except 45.22 fron Vol. 7.

(b) This nethod was used to determine gadol iniun in experiment solution.

(c) This method was used to determine gadoliniun in the concentrated gadoliniun nitrate solution. 
Appendix C). The ${ }^{241}$ Am content for each sample analyzed, the analysis date and the experiments covered by that sample are given in Table 3.3. The isotopic analysis values for the plutonium-uranium nitrate solutions used in the experiments are given in Table 3.4. Table 3.5 provides information on the temperatures of the critical assembly room (CAR), the dump mix tank (DM) and the water reflector. Also in Table 3.5, the reflector water level and the position of the bottom of the control and safety blades are given (reference is the vessel top).

Appendix $D$ provides chemical analysis data and analysis calculations for the gadolinium in the experimental solutions.

Appendix E provides data on the chemical analyses for the impurities found in the plutonium-uranium nitrate solutions.

The chemical analyses of the reflector water samples are given in Appendix F.

\subsection{SOURCES OF ERROR}

It is practically impossible to assess, individually, the effects of all the uncertainties in all of the experimental measurements. Realistically, it is only necessary to examine those variables or combination of variables which might have a reactivity effect which is a significant fraction of the typical uncertainty in a particular KENO computer code calculation. This evaluation was done for the significant measurements involved in earlier experiments and reported (Primm 1986). From that analysis it was found that the primary uncertainty that caused significant error was from the free acid values. Since those measurements, a study was made and a free acid analysis method developed and reported (Ryan 1985). This has significantly reduced uncertainties in the analysis for free acid. Further work provided free acid standards so that the analyses could be confirmed. 
TABLE 3.3 Chemical Analysis Values for Americium-241

$\begin{array}{ccc}\begin{array}{c}\text { Sample } \\ \text { Number }\end{array} & \begin{array}{c}241_{\text {Am }} \\ (\mathrm{ug} / \mathrm{ml})\end{array} & \begin{array}{c}\text { Analysis } \\ \text { Date }\end{array} \\ 1232 & 265 & 12 / 16 / 87 \\ 1235 & 573 & 12 / 16 / 87 \\ 1263 & 453 & 04 / 29 / 88\end{array}$

(a) The analysis 5egults from samples 1232, 1235 and 1263 can be used to estimate the ${ }^{241}$ Am concentrations for experiments 106, 106R, 107, 110 and $110 R$ using the ratio based on plutonium concentration. The plutonium concentration for sample 1232 was $47.08 \mathrm{~g} \mathrm{Pu} / 11$ ter.

Sample 1232 covers experiment 109

Sample 1235 covers experiments 111 to 116

Sample 1263 covers experiment 117 
TABLE 3.4 Isotopic Analysis Values of Plutonium and Uranium (a)

Sample 1232

$p_{u}^{(b)}$

238

239

240

241

242

$\underline{u}^{(c)}$

238

238

235

234
$12 / 14 / 87$

$0.046 \pm 0.005$

$91.11 \pm 0.04$

$8.33 \pm 0.84$

$0.419 \pm 0.02$

$0.095 \pm 0.001$

$12 / 14 / 87$

$99.234 \pm 0.668$

$.053 \pm 6.685$

$0.705 \pm 0.608$

$0.088 \pm 0.001$
Sanple 1235

$12 / 14 / 87$

$0.032 \pm 0.064$

$91.12 \pm 0.04$

$8.33 \pm 0.84$

$0.419 \pm 0.62$

$0.696 \pm 0.661$

$12 / 14 / 87$

$99.232 \pm 0.668$

$0.053 \pm 0.805$

$0.769 \pm 0.668$

$0.007 \pm 0.001$

(a) All values given in wty. An average of these isotopic results should be used for all exporiments.

(b) Date of Pu analysis

(c) Date of U analysis 
TABLE 3.5 Information on Temperature, Reflector Leve1, and Control and Safety Blade Position

\begin{tabular}{|c|c|c|c|c|c|}
\hline \multirow{2}{*}{$\begin{array}{l}\text { Experiment } \\
\text { Number }\end{array}$} & \multicolumn{3}{|c|}{ Temperature ${ }^{\circ} \mathrm{C}$} & \multirow{2}{*}{$\begin{array}{l}\text { Ref loctor Lovel } \\
\text { Distance Bo low } \\
\text { Vessol Top (ca) }\end{array}$} & \multirow[t]{2}{*}{$\begin{array}{c}\text { Control and Safety } \\
\text { Blade Distance } \\
\text { Below Vessel } \\
\text { Top (cm) } \\
\end{array}$} \\
\hline & CAR & DM Tank & Rof loctor & & \\
\hline 186 & 25.2 & 24.1 & $: 24.0$ & 56 & 47 \\
\hline $196 R$ & 24.2 & 24.0 & 23.7 & 56 & 47 \\
\hline 107 & 24.3 & 23.9 & 23.3 & 56 & 47 \\
\hline 109 & 24.0 & 22.6 & 21.4 & 56 & 47 \\
\hline 110 & 24.1 & 22.4 & 21.3 & 56 & 47 \\
\hline I1⿴R & 23.6 & 22.5 & 22.1 & 56 & 47 \\
\hline 111 & 23.8 & 24.4 & 20.8 & 56 & 47 \\
\hline 112 & 23.9 & 24.7 & 19.1 & 56 & 47 \\
\hline 113 & 23.6 & 24.7 & 21.9 & 56 & 47 \\
\hline 114 & 22.7 & 24.2 & 17.9 & 56 & 47 \\
\hline 115 & 22.6 & 23.4 & 17.4 & 56 & 47 \\
\hline 116 & 22.8 & 23.0 & 18.1 & 66 & 47 \\
\hline 117 & 28.2 & 22.3 & 21.4 & 56 & 47 \\
\hline
\end{tabular}


The latest estimated values of uncertainties are listed in Table 3.6.

TABLE 3.6 Estimate of Measurement Uncertainties

$$
\begin{array}{ll}
\text { Pu Concentration } & \neq 0.2 \% \\
\text { U Concentration } & \neq 0.2 \% \\
\text { Density } & \neq 0.0003 \mathrm{~g} / \mathrm{cm}^{3} \\
\text { Free Acid } & \neq 0.04 \mathrm{M} \\
\text { Critical Height } & \neq 1.6 \mathrm{~mm}
\end{array}
$$

The uncertainty values for the chemical analyses were provided by M. C. Burt of the Chemical and Analysis Section. The critical height uncertainty is given as $1.6 \mathrm{~mm}$ although the least square fitting of approach data for three counting systems would indicate a smaller value as reasonable. The $1.6 \mathrm{~mm}$ unit is the smallest. on the sight tube. 


\subsection{ACKNOWLEDGMENTS}

The work performed for this report required the cooperation and assistance of a number of people, some of whom are listed below. Their contributions are greatly appreciated.

- E. D. Clayton for information and guidance on technical matters.

- M. C. Burt for providing accurate chemical analyses of solutions in a timely manner.

- J. H. Smith and M. A. Covert for providing valuable advice, and assistance in performing the experiments.

- D. A. Costanzo for providing advice regarding chemical analysis methods.

- C. A. Strand for providing as-built data on the FFTF fuel pins.

- L. N. Terry for typing, proofreading and guidance in preparation of this report. 


\subsection{REFERENCES}

Bterman, S. R., et. al., (1979). Critical Experiments with Fast Test Reactor Fuel Pins in Water. Nuclear Technology. 44: 141-151.

Bierman, S. R. (1986). Critical Experiments with Fast Test Reactor Fuel Pins in an Organic Moderator. PNL-5803, Pacific Northwest Laboratory, Richland, Washington.

Clayton, E. D. (1985). Neutron Source Multiplication Method, PNL-SA-13357, Pacific Northwest Laboratory, Richland, Washington.

Durst, B. M. et. al., (1980). Critical Experiments with Solid Neutron Absorbers and Water-Moderated Fast Test Reactor Fuel Pins. Nuclear Technology. 48: 128-149.

Lloyd, R. C. (1986). Critical Experiments with Mixed Plutonfum and Uranium Nitrate Solution at a Plutonium Fraction of 0.5 in STab and Cylindrical Geometry. PNL-5768, Pacific Northwest Laboratory, Richland, Washington.

Primm, R. T. III and J. F. Mincey. (1980). Calculated $k$ for for Partially Concrete-Reflected FTR Pins in Water. Transactfons American Nuclear Soctety. 35: 288-290.

Primm, R. T. III, et. al., (1986). Critical Experiments with Mixed Plutonium-Uranium Nitrate Solutions having Pu/(Pu $+U)$ Ratios Greater than 0.5. ORNL-6161, Oak Ridge National Laboratory, Oak Ridge, Tennessee.

Ryan, J. L., et. al., (1985). "Preparation of Acid Standards for and Determination of Free Acid in Concentrated Plutonium-Uranium Solutions." Analytical Chemistry. 57:1423. 
APPENDIX A

A LISTING OF ENGINEERING DRAWINGS FOR THE CYLINDRICAL VESSEL SYSTEM 


\section{APPENDIX A}

\section{A LISTING OF ENGINEERING DRAWINGS FOR THE CYLINDRICAL VESSEL SYSTEM}

CFRP Assembly H-2-33856, Sheet 1 of 5

CFRP $\mathrm{H}_{2} \mathrm{O}$ Tank and Cover $\mathrm{H}-2-33856$, Sheet 2 of 5

CFRP Process Tanks H-2-33856, Sheet 3 of 5

CFRP Tank Covers and Shield H-2-33856, Sheet 4 of 5

CFRP Dump Valve H-2-33856, Sheet 5 of 5

A. 1 


\section{APPENDIX B}

\section{ENGINEERING DRAWINGS OF THE BOILER TUBE-TYPE TANK ASSEMBLY}




\section{APPENDIX C}

LEAST SQUARE FITS OF THE CRITICAL APPROACH DATA 


\section{APPENDIX C}

\section{LEAST SQUARE FITS OF THE CRITICAL APPROACH DATA}

The extrapolated values given are for solution height in the boller tube-type tank. The solution height values used in these plots are given in inches. The solution height is the height of the solution above the polyethylene spacer which is also the level where the mixed oxide fuel in the fuel pins begin. 


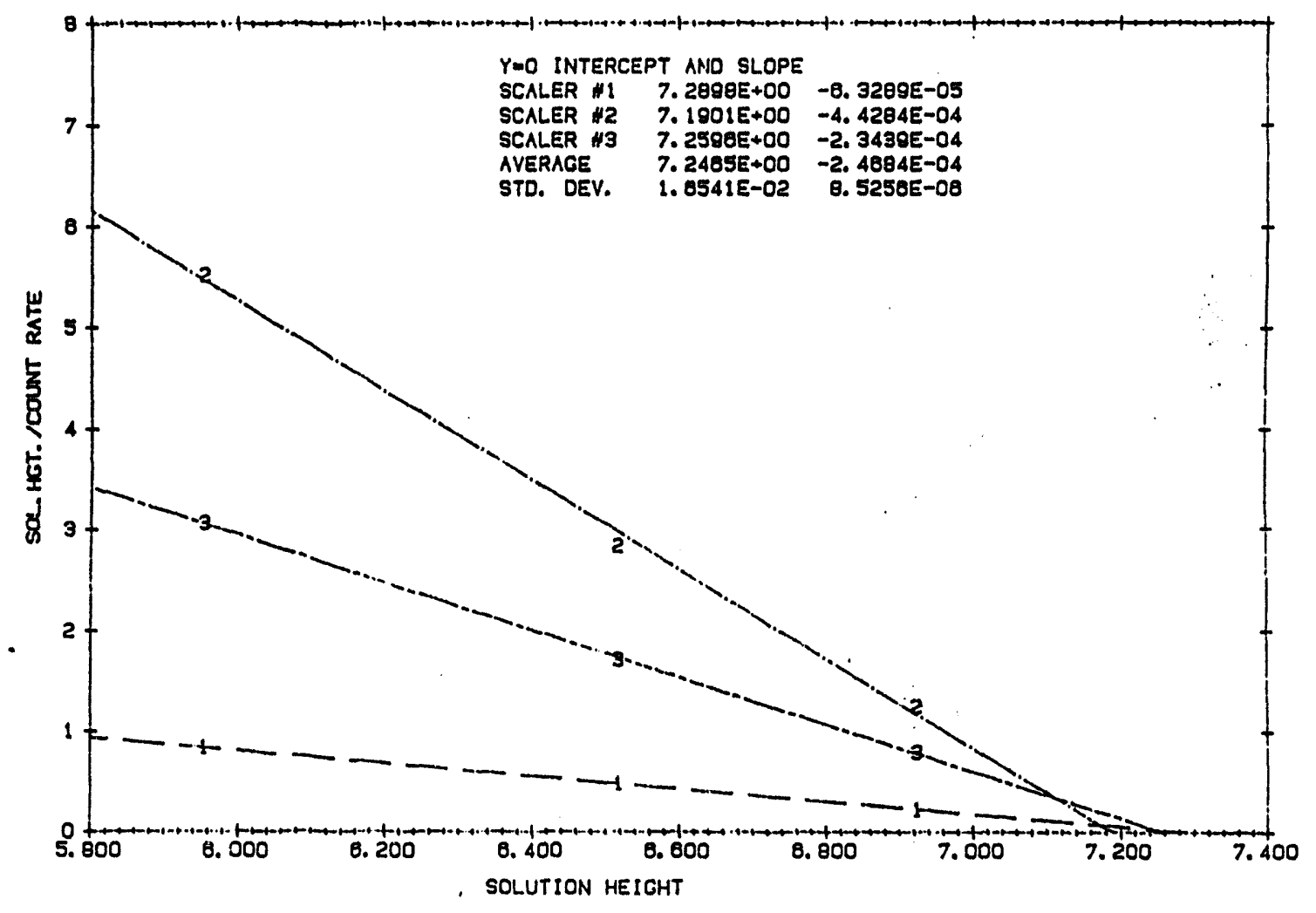

FIGURE C.1 Least Square Fits for CFRP-PNC 106 


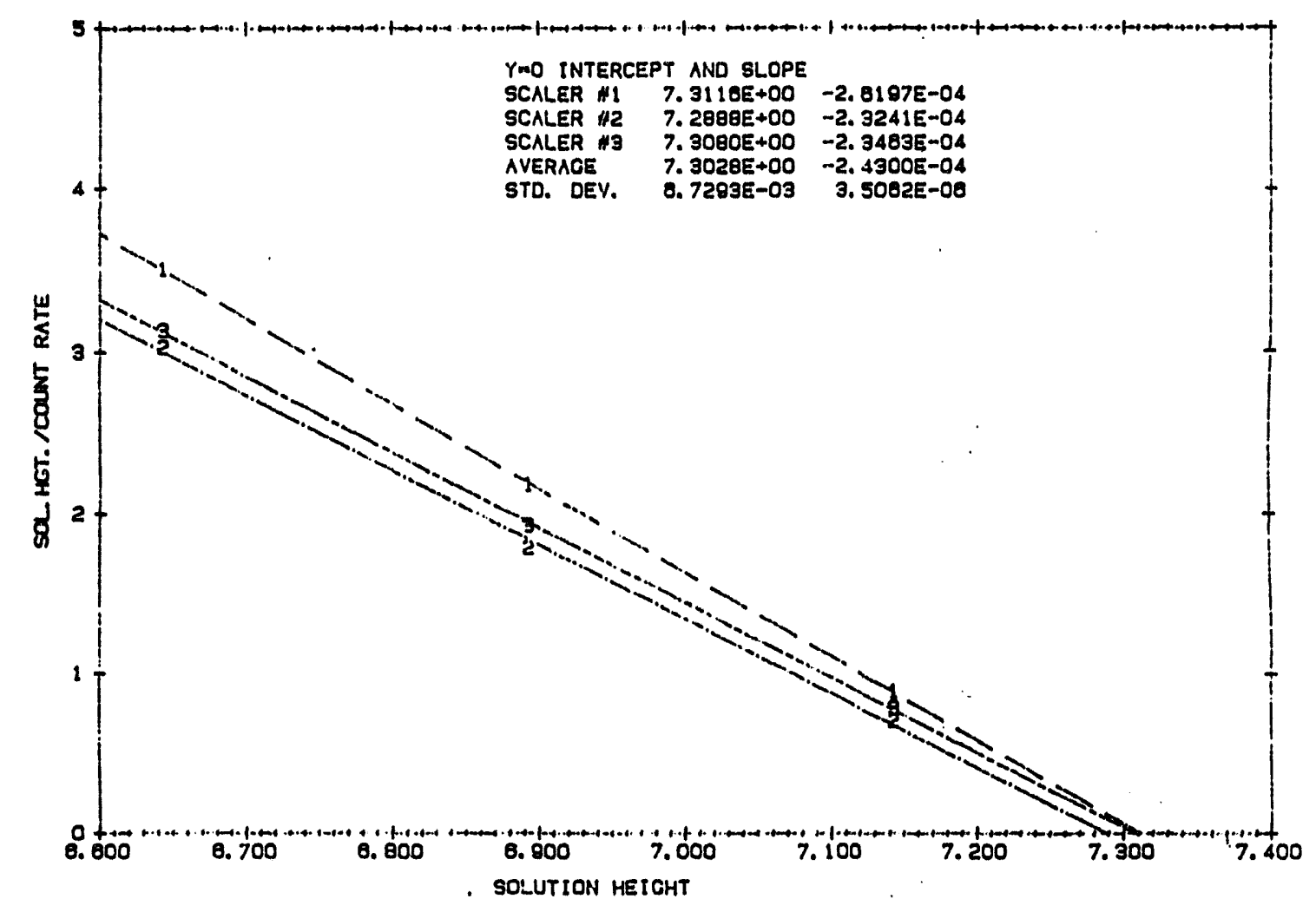

FIGURE C.2 Least Square Fits for CFRP-PNC 106R 


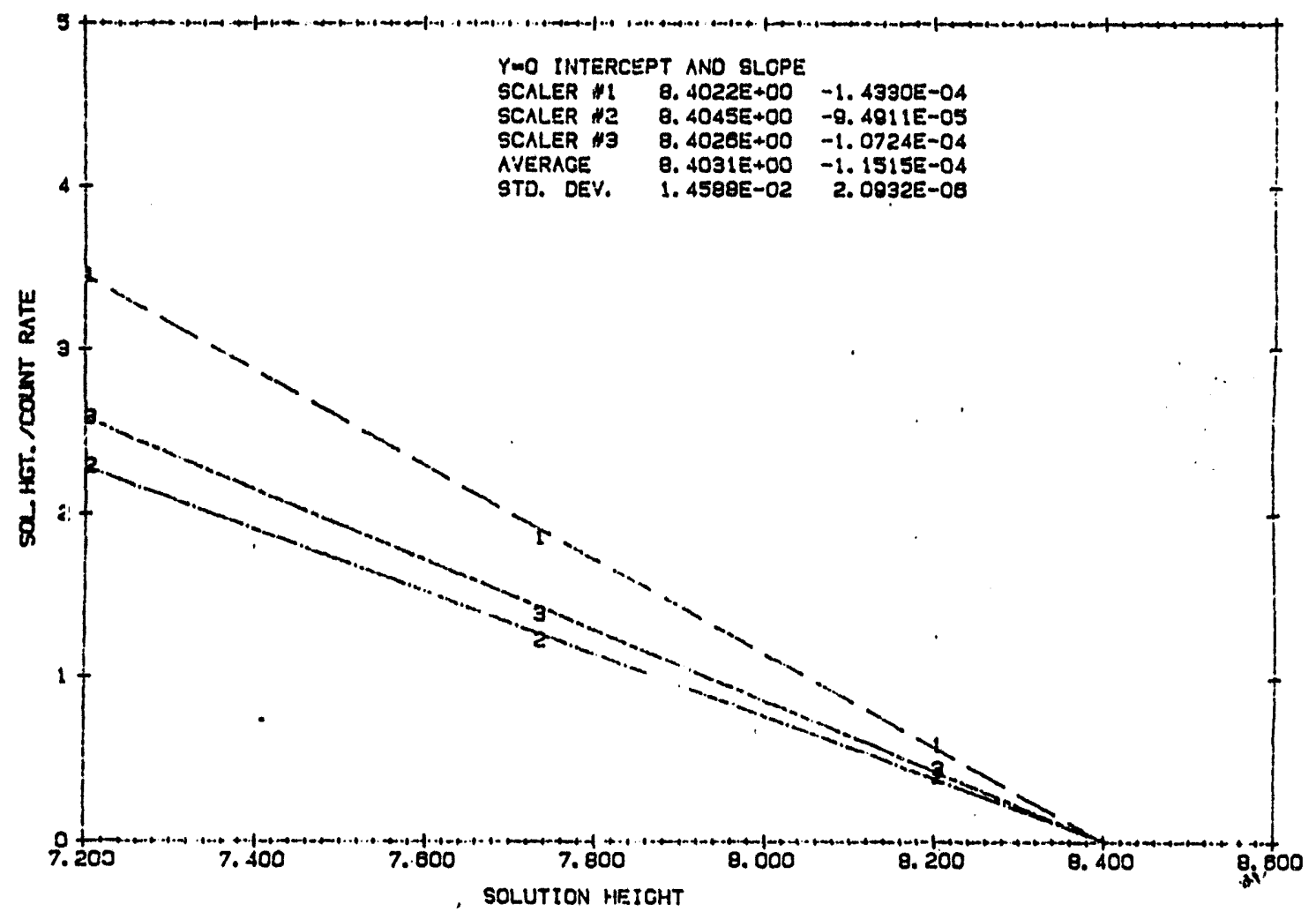

FIGURE C. 3 Least Square Fits for CFRP-PNC 107 


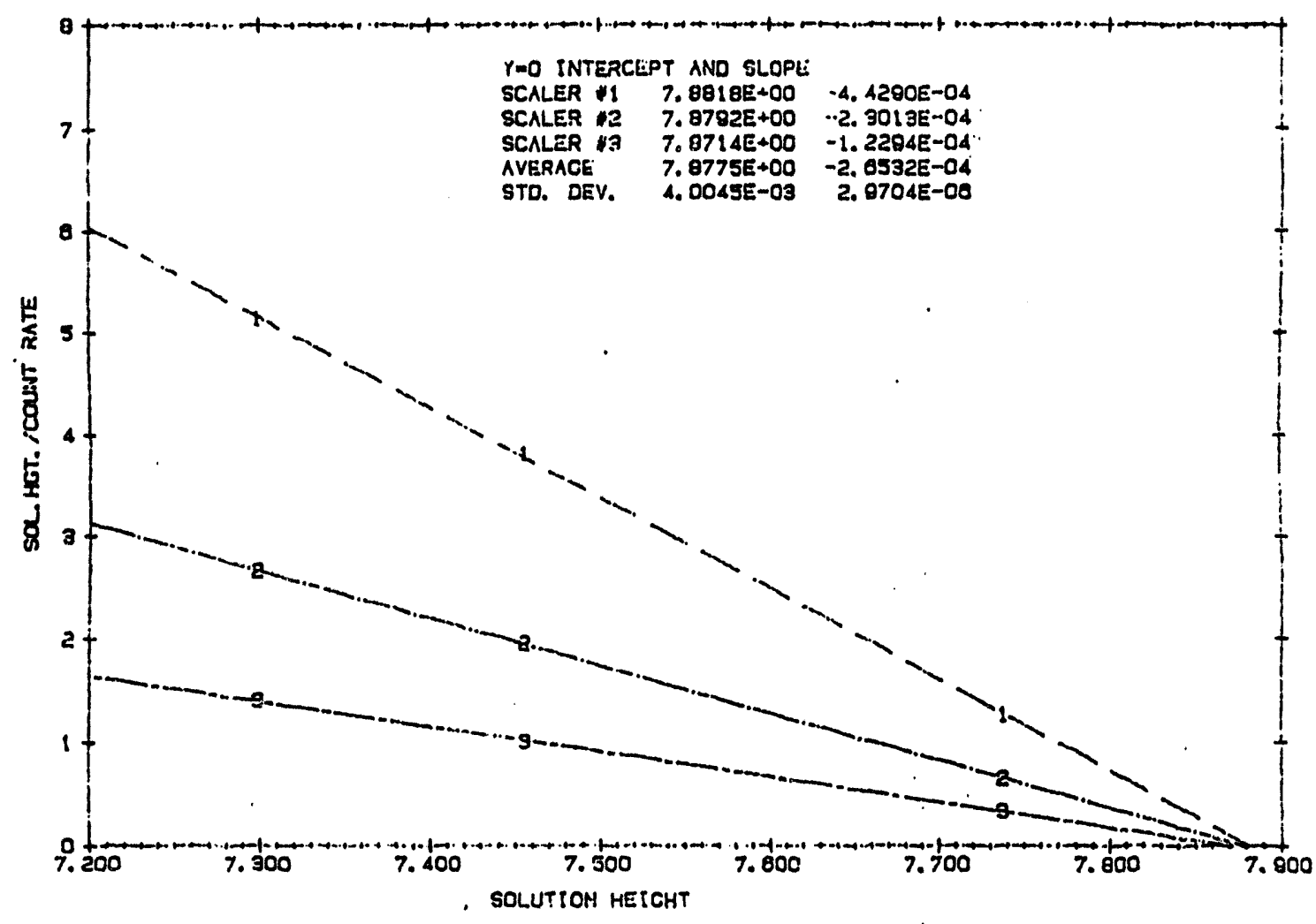

FIGURE C.4 Least Square Fits for CFRP-PNC 109

C.5 


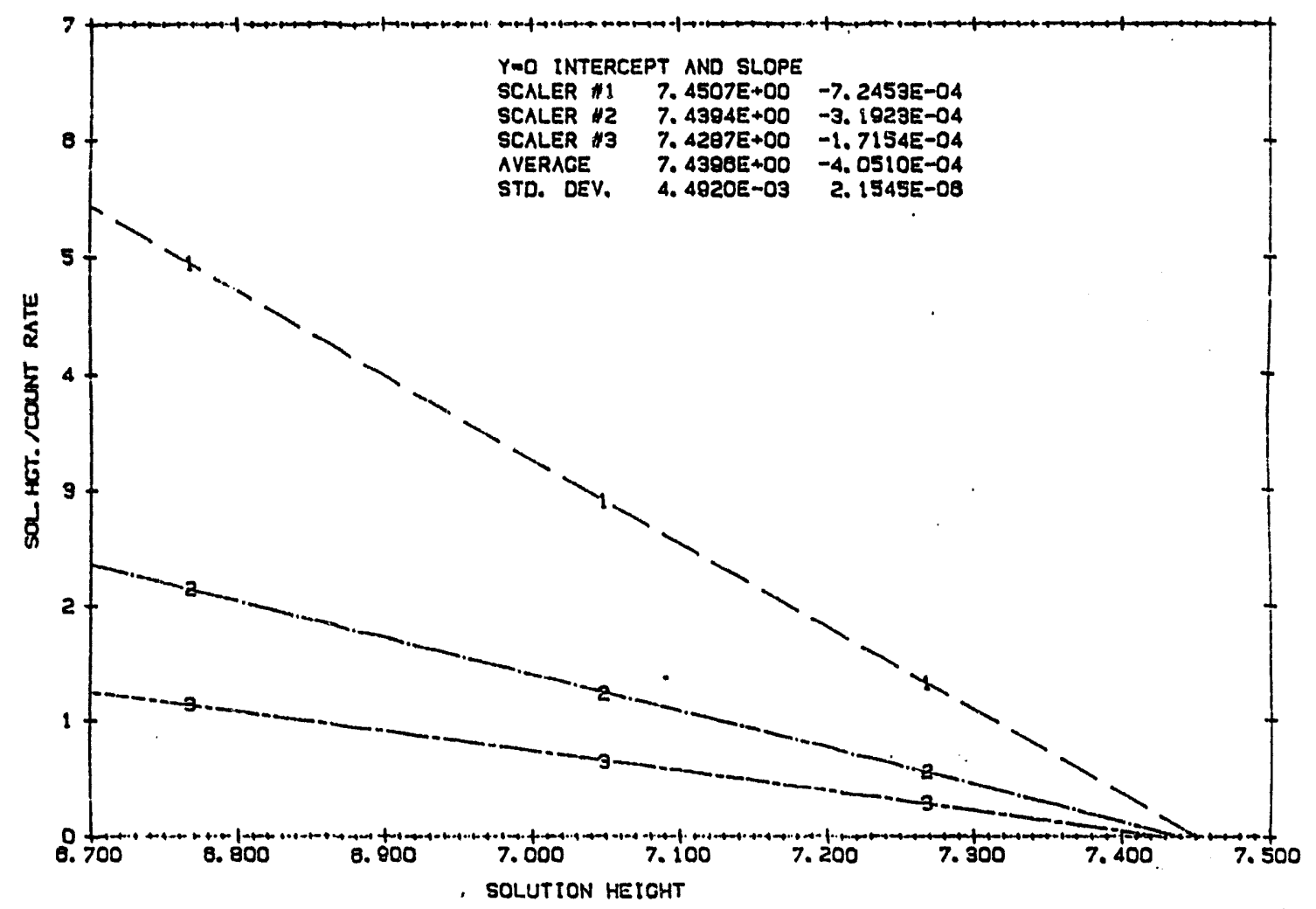

FIGURE C.5 Least Square Fits for CFRP-PNC 110 


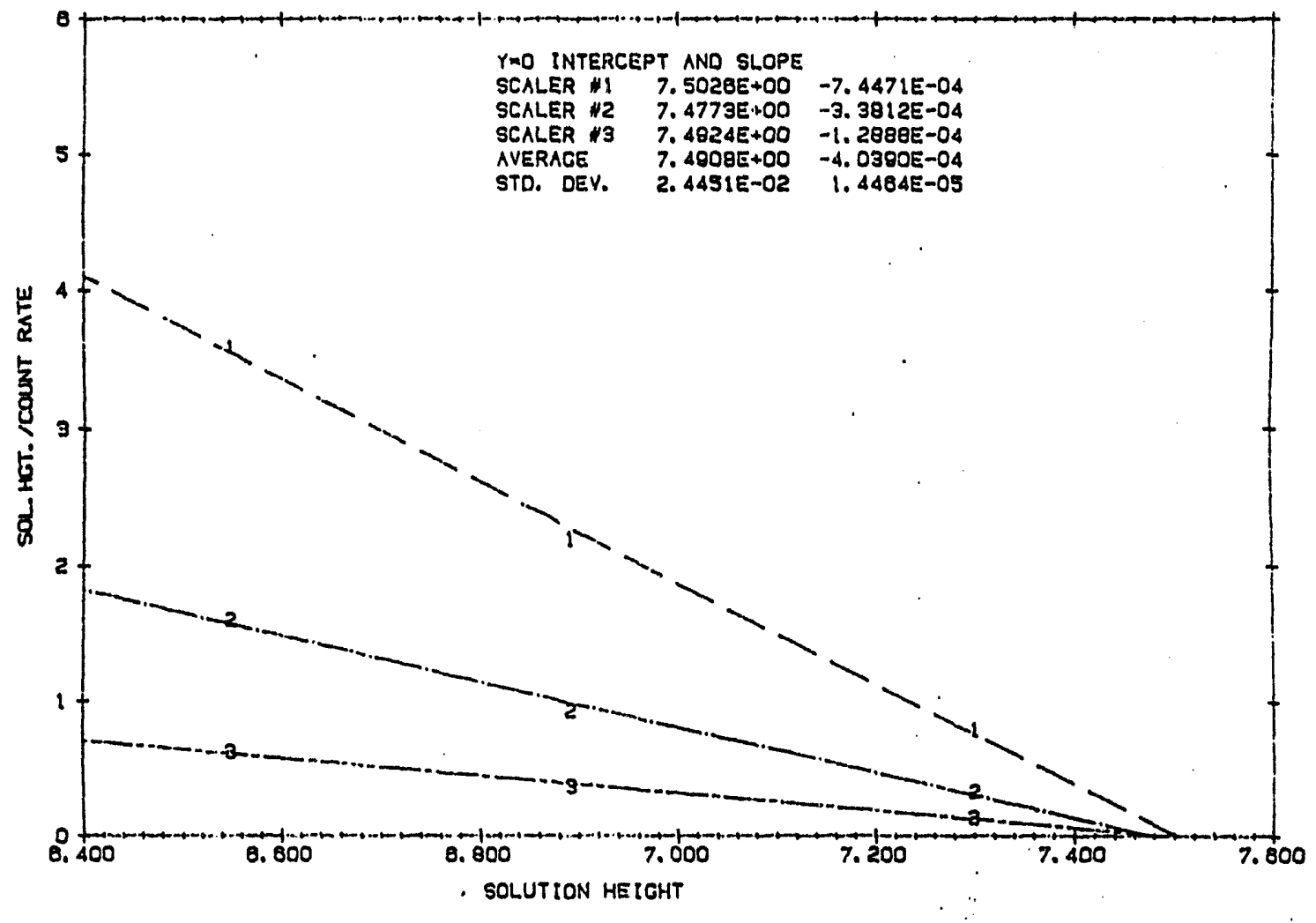

FIGURE C.6 Least Square Fits for CFRP-PNC 110R 


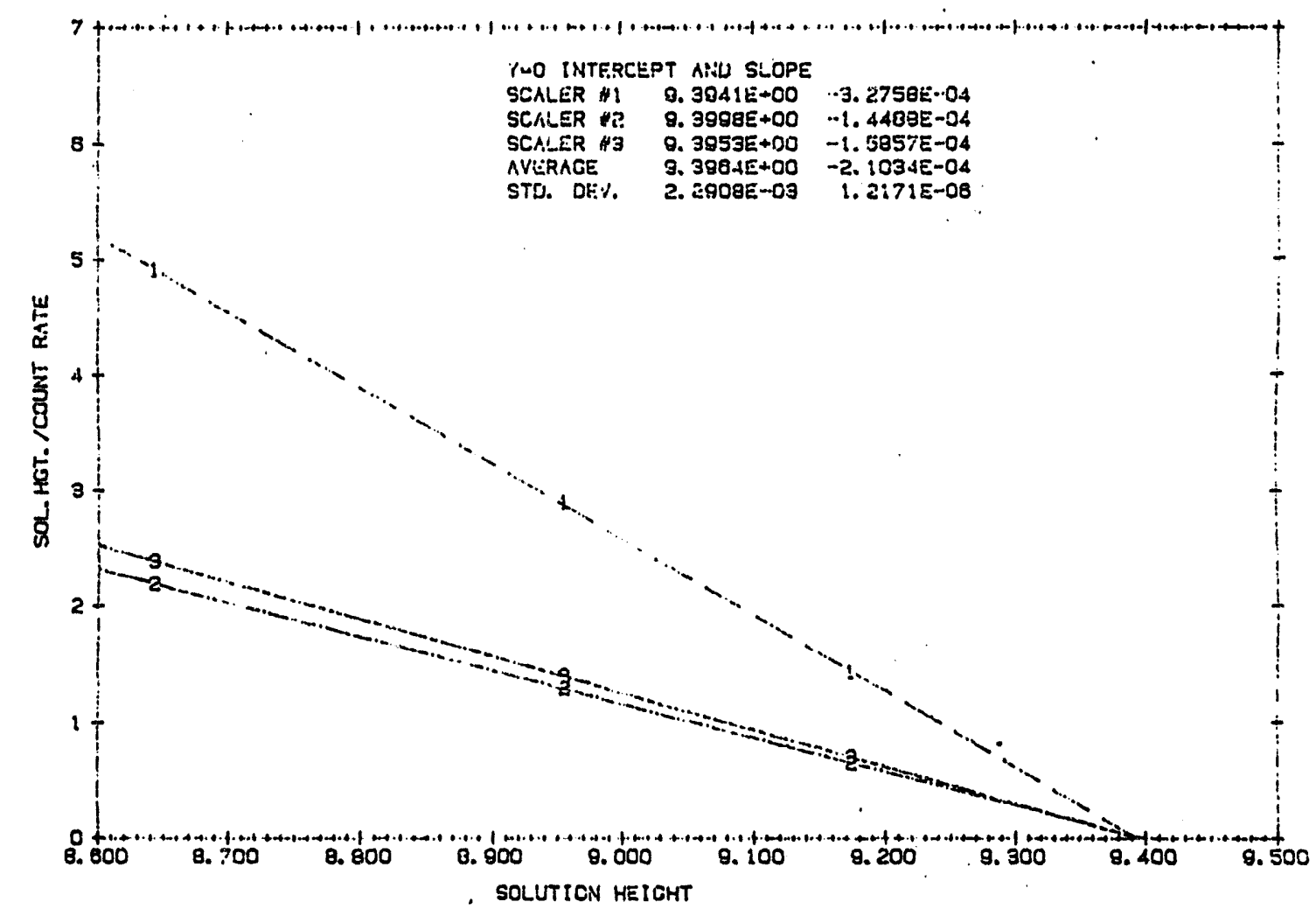

FIGURE C.7 Least Square Fits for CFRP-PNC 111 


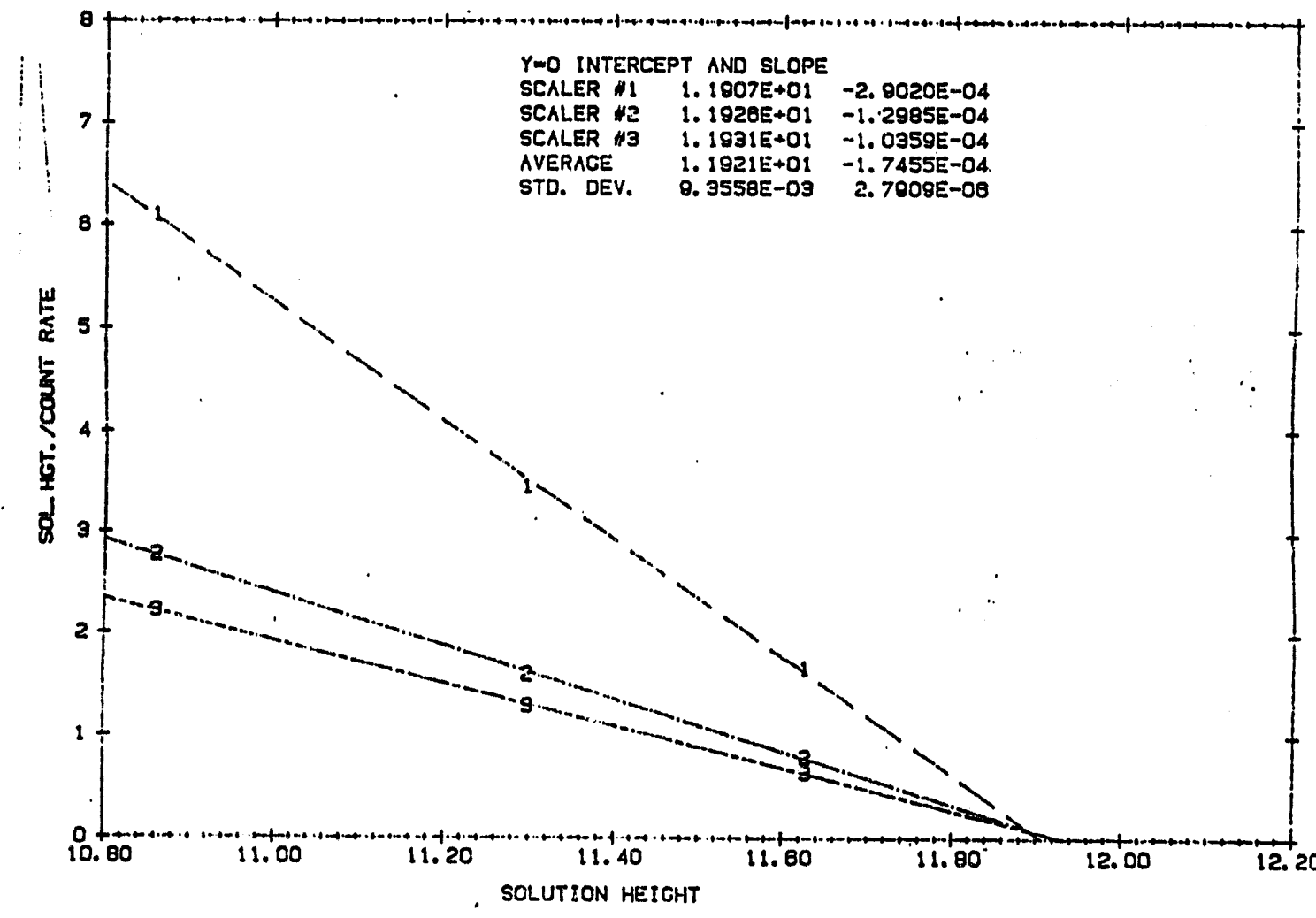

FIGURE C.8 Least Aquare Fits for CFRP-PNC 112 


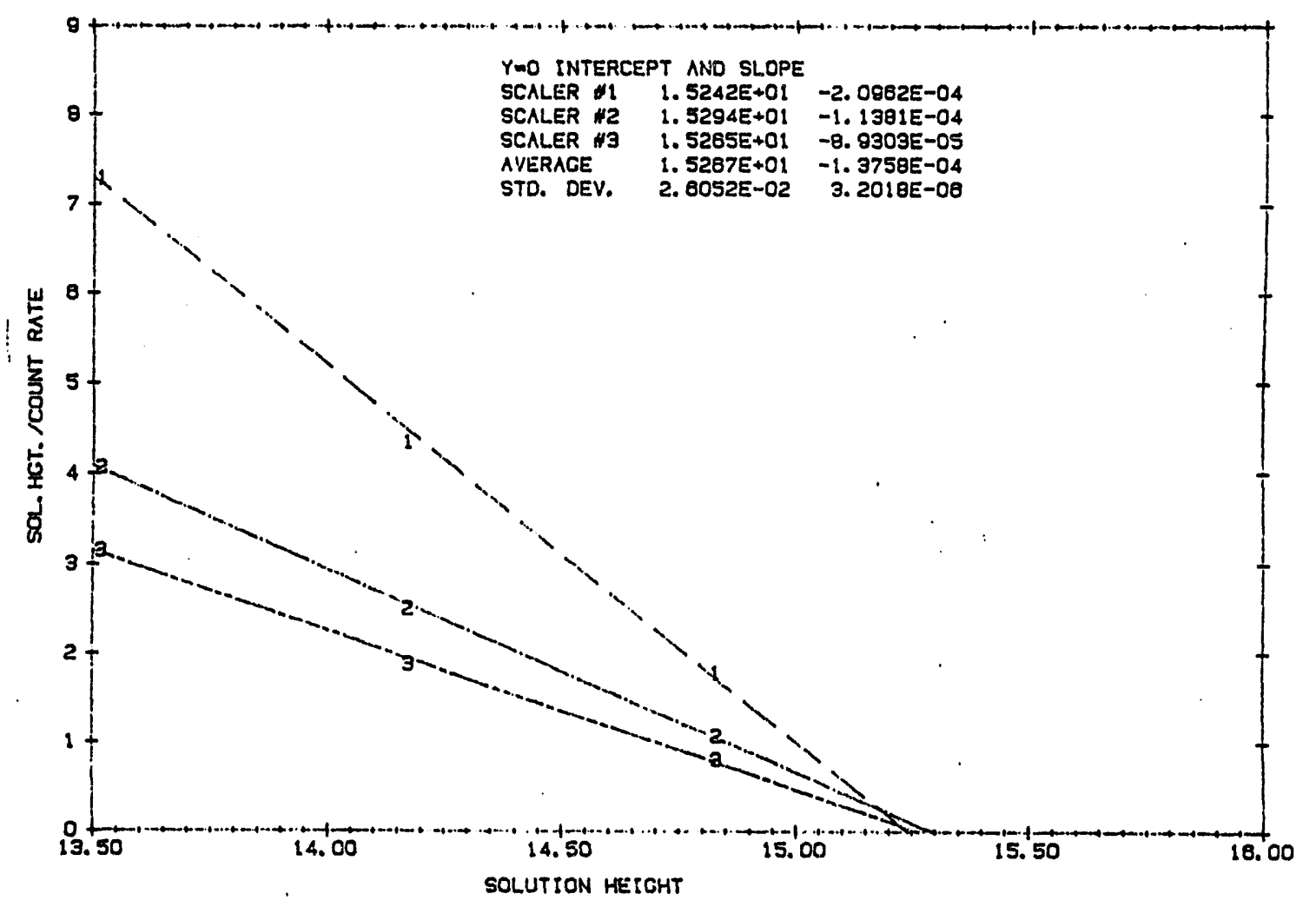

FIGURE C.9 Least Square Fits for CFRP-PNC 113 


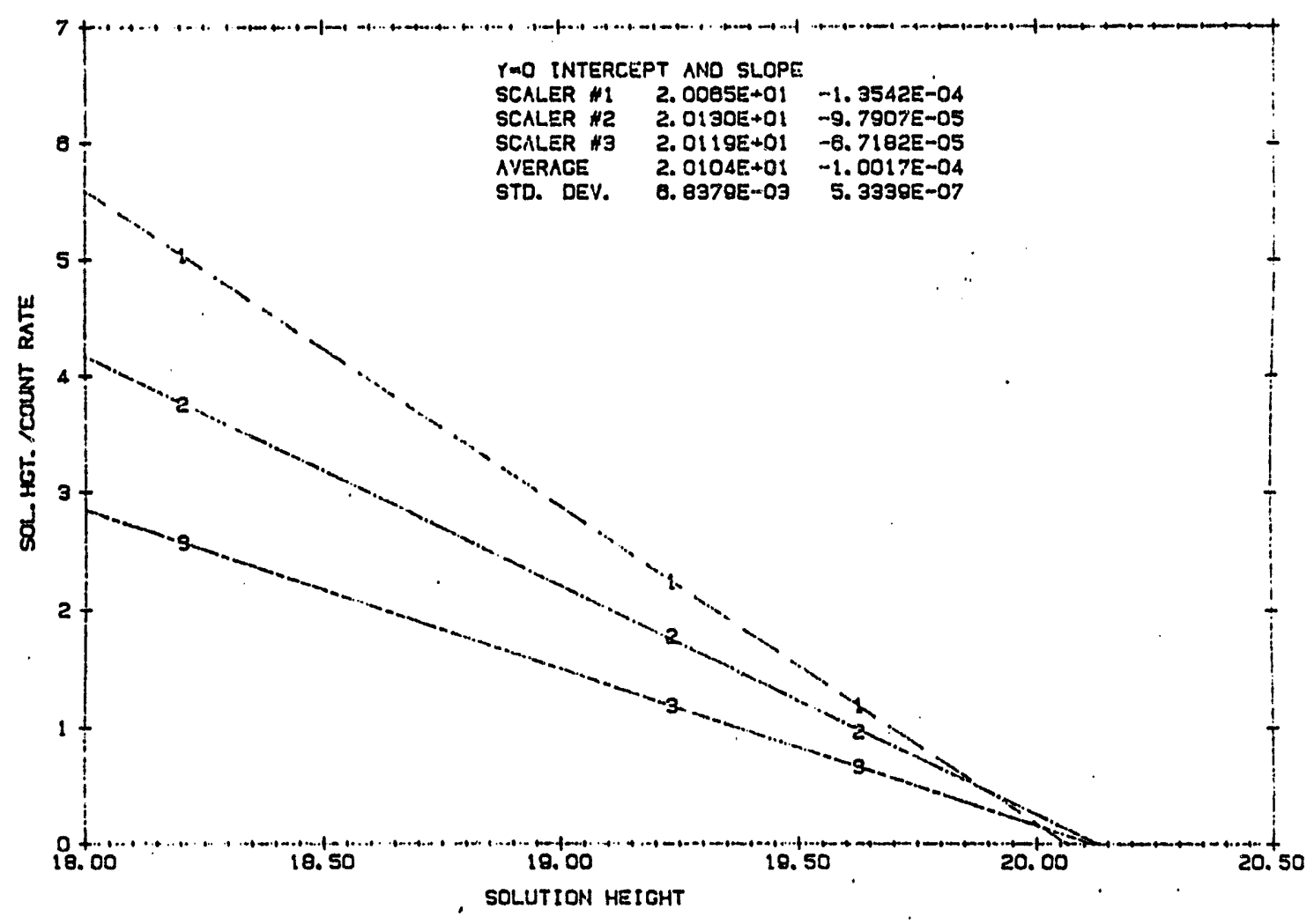

FIGURE C. 10 Least Square Fits for CFRP-PNC 114 


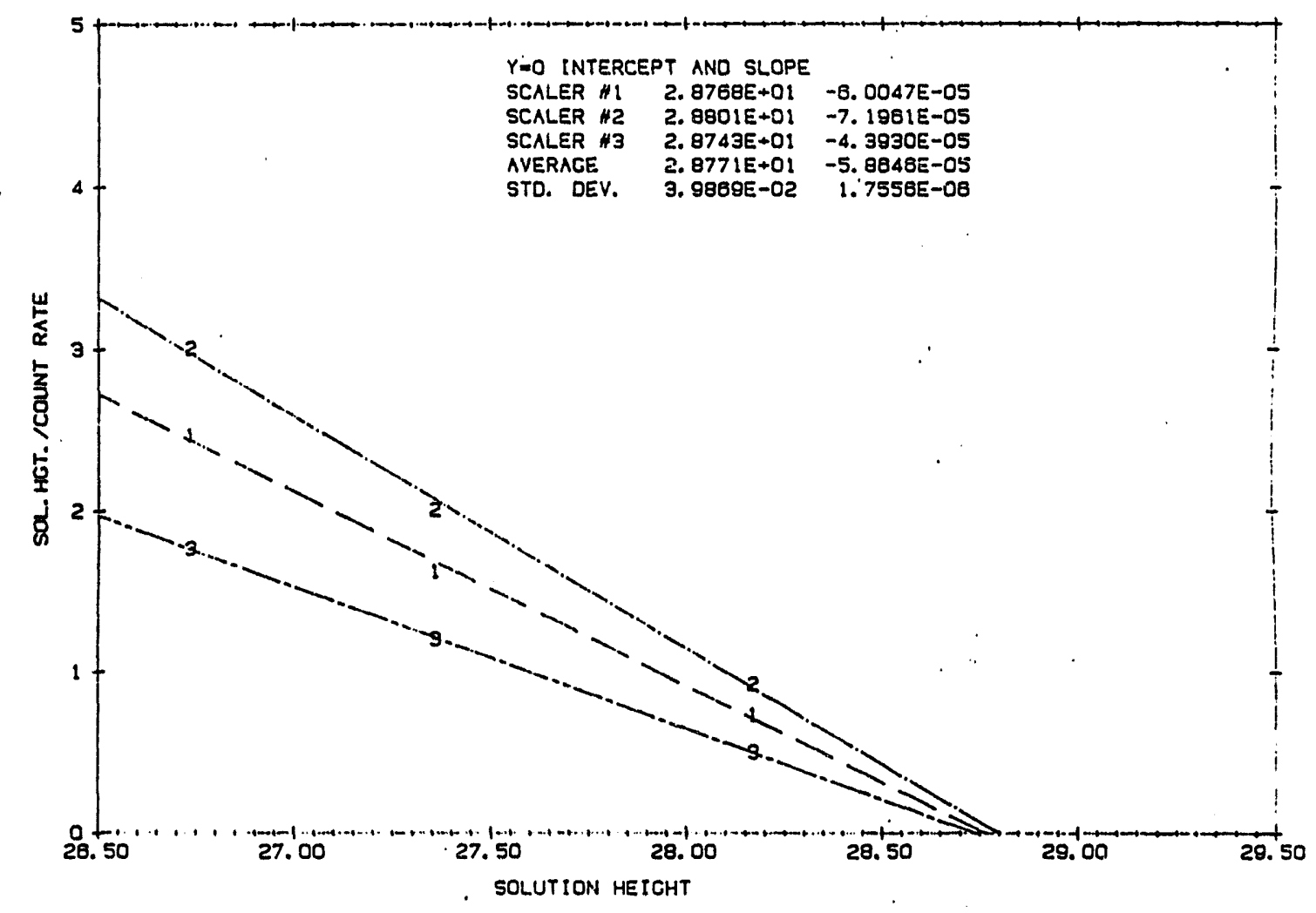

FIGURE C. 11 Least Square Fits for CFRP-PNC 115 


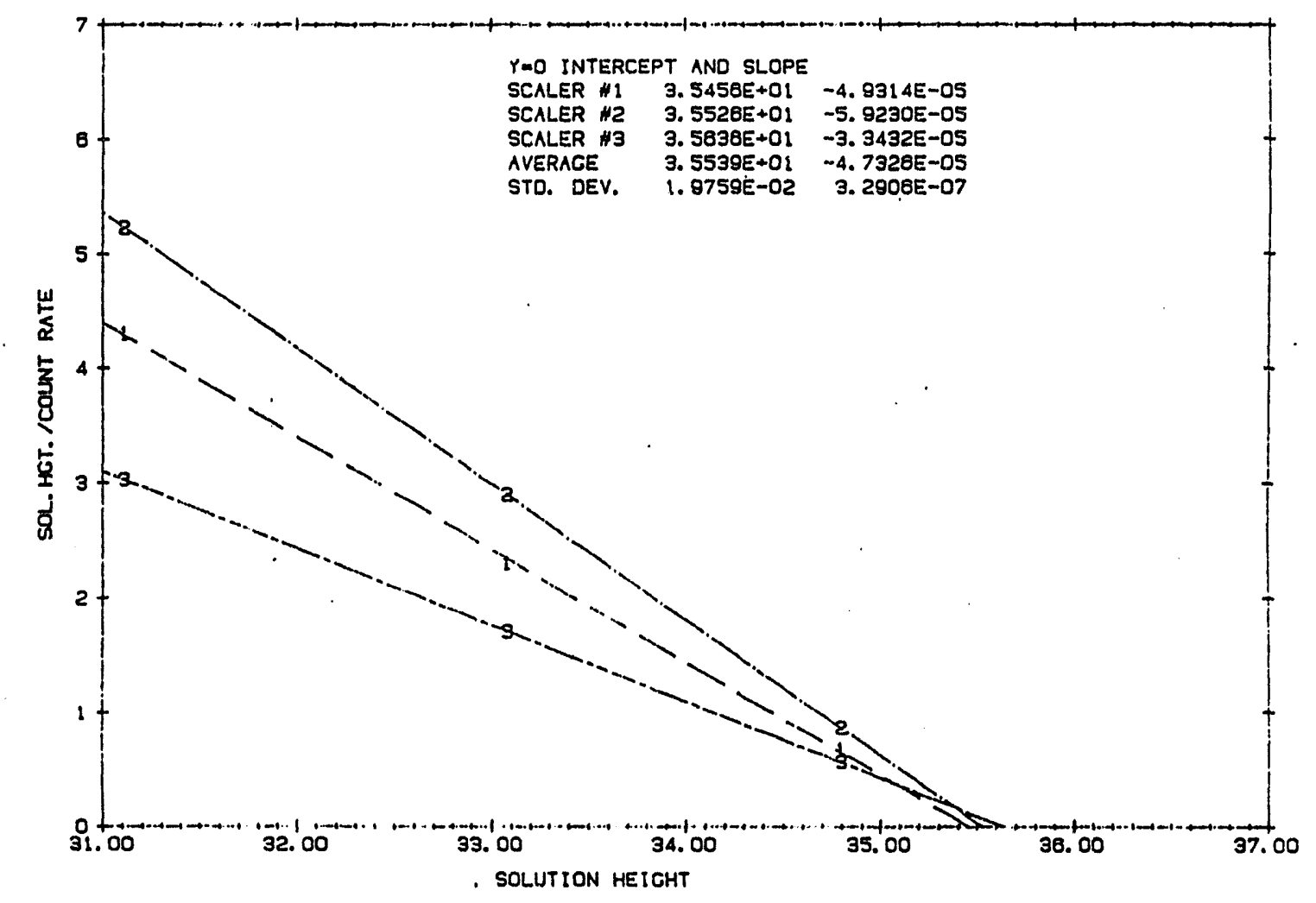

FIGURE C.12 Least Square Fits for CFRP-PNC 116 


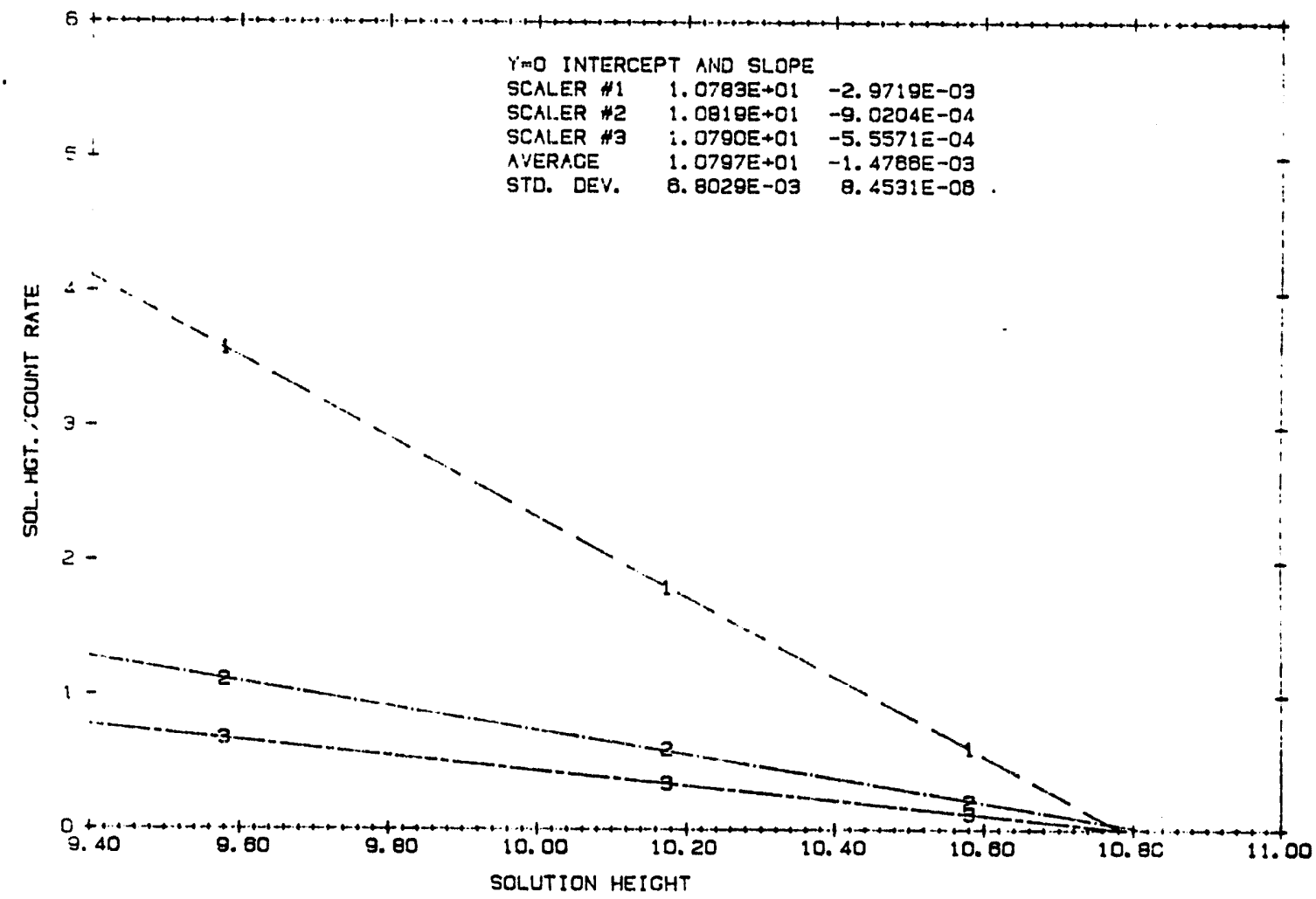

FIGURE C.13 Least Square Fits for CFRP-PNC 117 


\section{APPENDIX D}

ANALYSIS OF GADOLINIUM CONCENTRATION DATA 
APPENDIX D

\section{ANALYSIS OF GADOLINIUM CONCENTRATION DATA}

Initially, it was necessary to determine the amount of gadolinium to add to the fissile solution so that the experiment solutions would have gadolinium concentrations close to expected values. The gadolinium was added in the form

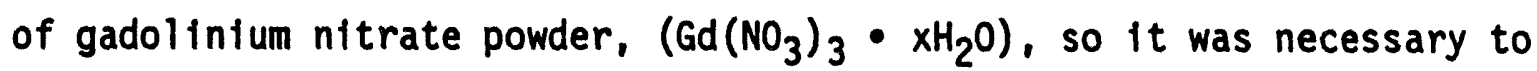
evaluate the fraction of gadolinium in the molecule. Based on two independent analyses, Loss on Ignition and Inductively Coupled Plasma Spectroscopy (ICP), the fraction of gadolinium to gadolinium nitrate powder was determined to be $0.367 \neq 0.006$, and the amount of water, $x$, was estimated to be $4.8 \neq 0.4$. Using measured amounts of gadolinium nitrate powder, water and nitric acid, five concentrated gadolinium solutions were prepared. The quantities of. materials used to prepare the concentrated gadolinium solutions are given in Table D.1. This table also gives the amount of gadolinium and volume of concentrated solution that was added to the bulk fissile solution stored in the dump mix tank to obtain the diluted gadolinium concentrations used in the critical experiments. For example, to obtain the $0.5 \mathrm{~g} \mathrm{Gd} / 1$ ter solution, 1.1029 liters of concentrated solution with $107.69 \mathrm{~g}$ of gadolinium was added to the existing volume (214 liters) of fissile solution in the dump mix tank. This process was continued with each of the concentrated gadolinium solutions to obtain the progressively higher gadolinium concentrations used in the critical experiments. As a check, estimates of the diluted gadolinium concentrations for solutions used in the critical experiments were made and are given in Table D.1. Although the precision of these results is very good, the accuracy of the gadolinium concentration is approximately $\neq 0.2 \%$ due to the uncertainty in the amount of gadolinium associated with the gadolinium nitrate powder.

A second method of determining the gadolinium concentrations of the experiment solutions used analytical data from the concentrated gadolinium solutions that were prepared. The densities and gadolinium concentrations of 
these solutions were measured and are given in Table 0.2. Since these solutions did not contain plutonium and uranium the ICP analyses were simplified. Estimates of the gadolinium concentrations of the experimental solutions were made using the analytical data given in Table 0.1 (column 7 , volume) and 0.2 (gadolinium concentration). The gadolinium concentration estimates are given in Table D.3. The uncertainty in these results is estimated to be $\neq 2 \%$.

A third method of determining the gadolinium concentrations was based on an ICP analysis of samples of the experimental solutions. However, the analysis of gadolinium concentration in the critical experiment solutions was difficult because the plutonium and uranium had to be separated from the solution prior to assay. The separation was performed by contacting the sample solutions with an equal volume of $30 \%$ tributyl phosphate in hexane. The organic layer was discarded after each phase separation. The solution was adjusted to $3 M$ acid and two contacts were made. Two more contacts were made after an acid adjustment to $4 M$. The extraction process also removes some of the gadolinium from the aqueous solution so that analytical studies were performed to evaluate the characteristics of the recovery curve over the concentrations of interest ( $1 . e ., 0-2 \mathrm{~g} / 11$ ter). The results of the studies showed that 10 - $20 \%$ of the gadolinium was lost in the separation procedure. The large variation in the amount of gadolinium that was recovered for each sample resulted in a high degree of uncertainty in the results obtained with this procedure. To determine the recovery (calibration) curve for the ICP analysis of the critical experiment solutions, $1 \mathrm{ml}$ quantities of sample number 1235 were spiked with $0,500,1000,1500$, and $2000 \mu \mathrm{g} \mathrm{Gd}$. The results of this analysis are shown in Table D.4. The following equation, based on a linear regression analysis of the data, was used to determine the actual gadolinium concentrations from the ICP results:

$$
x=1.1709 y+0.01614
$$

where $y$ is the concentration of gadolinium in $\mathrm{g} /$ liter as determined by the ICP analysis, and $x$ is the actual gadolinium concentration in $g / 1+$ ter. The coefficient of determination, $r^{2}$ is 0.996 . The results from the ICP analysis 
of the critical experiment solutions and the computed actual gadolinium concentrations are given in Table D.5. The uncertainty in these results is estimated to be $₫ 4 \%$.

A summary of the estimated gadolinium concentration results for the experimental solutions by the three methods is given in Table D.6. The data in the last column are the recommended values based on the results using the second method. The values include the estimated impurity concentration of gadolinium, $0.002 \mathrm{~g} / 11$ ter. These recommended values are given in Table 3.1 of this report.

TABLE D.1 Analysis of Gadolinium Concentrations Based on ICP and Loss on Ignition Estimates of Fraction of Gadolinium in Gadolinium Nitrate Powder

\begin{tabular}{|c|c|c|c|c|c|c|c|c|}
\hline \multirow[b]{2}{*}{$\begin{array}{l}\text { Conc. Gd } \\
\text { Solution } \\
\text { Number } \\
\end{array}$} & \multicolumn{4}{|c|}{$\begin{array}{l}\text { Mass of Materials } \\
\text { Used to Prepare } \\
\text { Conc. Gd Solution }\end{array}$} & \multicolumn{2}{|c|}{$\begin{array}{l}\text { Amounts Added } \\
\text { to } \\
\text { Bulk Solution (a) }\end{array}$} & \multicolumn{2}{|c|}{ Bulk Solution } \\
\hline & $\begin{array}{l}\text { Water } \\
\text { (g) }\end{array}$ & $\begin{array}{l}\text { Nitric } \\
\text { Acid } \\
\text { (g) } \\
\end{array}$ & $\begin{array}{l}\text { Gd Nitrate } \\
\text { Powder } \\
\text { (g) } \\
\end{array}$ & $\begin{array}{c}\text { Total } \\
\text { (g) }\end{array}$ & $\begin{array}{l}G d^{(b)} \\
(g)\end{array}$ & $\begin{array}{l}\text { Volume } \\
\text { (11ter) }\end{array}$ & $\begin{array}{l}\text { Gd } \\
\text { Conc. } \\
\text { (g/liter) }\end{array}$ & $\begin{array}{l}\text { Bulk } \\
\text { Solution } \\
\text { Number } \\
\end{array}$ \\
\hline $\mathrm{Cl}$ & 975 & 46.1 & 295.29 & 1316.4 & 107.69 & 1.1029 & 0.501 & B-1 \\
\hline C2 & 781 & 37.0 & 298.00 & 1116.0 & 108.53 & 0.9052 & 1.001 & B-2 \\
\hline C3 & 781 & 37.0 & 300.19 & 1118.2 & 109.32 & 0.9041 & 1.501 & $B-3$ \\
\hline C4 & 781 & 37.0 & 302.41 & 1120.4 & 110.13 & 0.9032 & 2.000 & B-4 \\
\hline C5 & 781 & 37.0 & 124.48 & 942.5 & 45.31 & 0.8422 & 2.200 & B-5 \\
\hline
\end{tabular}

(a) Given amounts are those added to the bulk solution after subtracting quantities $1 \mathrm{n}$ the $7 \mathrm{ml}$ analytical samples.

(b) Calculated values. 
TABLE D.2 Analytical Data for Concentrated Gadolinium Solutions

\begin{tabular}{ccc}
$\begin{array}{c}\text { Conc. Gd. } \\
\begin{array}{c}\text { Solution } \\
\text { Number }\end{array}\end{array}$ & $\begin{array}{c}\text { Gd Conc. } \\
(\mathrm{g} / \text { iter })\end{array}$ & $\begin{array}{c}\text { Density } \\
\left(\mathrm{g} / \mathrm{cm}^{3}\right)\end{array}$ \\
\hline C1 & 95.91 & 1.1860 \\
C2 & 116.14 & 1.2234 \\
C3 & 118.52 & 1.2273 \\
C4 & 121.37 & 1.2310 \\
C5 & 53.30 & 1.1099
\end{tabular}

TABLE D.3 Analysis of Gadolinium Concentrations Based on Analytical Results of Concentrated Solutions

\begin{tabular}{|c|c|}
\hline $\begin{array}{c}\text { Bulk } \\
\text { Solution } \\
\text { Number } \\
\end{array}$ & $\begin{array}{c}\text { Bulk } \\
\text { Solution } \\
\text { Gd Conc. } \\
\text { (g/liter) }\end{array}$ \\
\hline B1 & 0.492 \\
\hline B2 & 0.976 \\
\hline B3 & 1.466 \\
\hline B4 & 1.964 \\
\hline B5 & 2.161 \\
\hline
\end{tabular}

TABLE D.4 Recovery Data for ICP Analysis

\begin{tabular}{cccc}
$\begin{array}{c}\text { Sample } \\
\text { Number }\end{array}$ & $\begin{array}{c}\text { Gd Added } \\
(\mu \mathrm{g})\end{array}$ & $\begin{array}{c}\text { Gd Recovered } \\
(\mu \mathrm{g})\end{array}$ & $\begin{array}{c}\text { Fraction } \\
\text { Recovered }\end{array}$ \\
\cline { 2 - 2 } & 0 & 1.8 & - \\
1235 & 500 & 414.5 & 0.829 \\
1235 & 1000 & 785 & 0.785 \\
1235 & 1500 & 1330 & 0.887 \\
1235 & 2000 & 1670 & 0.835 \\
1235 & & &
\end{tabular}

D. 4 
\begin{tabular}{c} 
Bulk \\
Solution \\
Number \\
\hline
\end{tabular}

$\begin{array}{ll}\text { B1 } & 1236 \\ \text { B2 } & 1237 \\ \text { B3 } & 1238 \\ \text { B4 } & 1239 \\ \text { B5 } & 1248\end{array}$

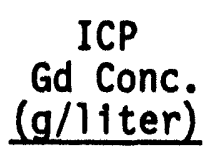

0.421

0.870

1.297

1.685

1.865
Actual

Gd Conc. (g/1iter)

0.509

1.035

1.535

1.989

2.200

TABLE D.6 Summary of Gadolinium Concentration Evaluations

Bulk Solution Number

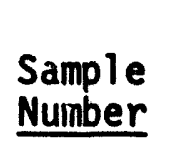

Method 1 (a)
(g/liter)

1236

0.501

1237

1.001

1238

1.501

2.000

1248

2.200

B5

B3

1239

Method $2^{(a)}$

Method 3

Recommended

Gd Conc.

0.492

0.509

0.49

0.976

1.035

0.98

1.466

1.535

1.47

1.964

1.989

1.97

2.161

2.200

2.16

(a) Methods 1 and 2 are based on gadolinium additions and do not include the residual $0.002 \mathrm{~g} / 1$ iter $\mathrm{Gd}$. The recommended values include the residual gadolinium. 


\section{APPENDIX E}

CHEMICAL ANALYSIS DATA OF THE IMPURITIES IN PLUTONIUM-URANIUM NITRATE SOLUTIONS 
The concentrations of impurity elements in the plutonium-uranium nitrate solutions were determined by analysis with the Inductively Coupled Plasma Atomic Emission Spectroscopy (ICP) method. The uncertainty in the ICP results is approximately $=25 \%$. The ICP analysis results for sample 1215 which cover experiment 107 are given in Table E.1. The ICP results for sample 1215 can be used to estimate the impurity concentrations in the other experiments (1.e., 106, 106R, 109, 110, 110R and 117) by multiplying the results by the ratio of plutonfum concentrations.

The ICP analysis results for samples $1235 \mathrm{~A}$ and $\mathrm{B}$ cover experiments 111 - 116 . 
TABLE E.1 Inductively Coupled Plasma

Spectroscopy Analyses (mg/liter)

\begin{tabular}{|c|c|c|c|}
\hline Element & $\begin{array}{c}\text { Sample } \\
\text { No. } 1215 \\
\end{array}$ & $\begin{array}{c}\text { Sample } \\
\text { No. } 1235 \mathrm{~A}\end{array}$ & $\begin{array}{c}\text { Sample } \\
\text { №. } 1235 \mathrm{~B} \\
\end{array}$ \\
\hline Al & 68.7 & 118 & 126 \\
\hline B & 3.0 & 7.95 & 10.5 \\
\hline $\mathrm{Ba}$ & 2.0 & 3.55 & 4.30 \\
\hline $\mathrm{Ca}$ & 41.0 & 65.4 & 72.9 \\
\hline Cd & 4.3 & 6.20 & 5.65 \\
\hline $\mathrm{Ce}$ & 4.2 & 6.50 & 8.00 \\
\hline $\mathrm{Cr}$ & 57.1 & 90.5 & 90.5 \\
\hline $\mathrm{Cu}$ & 12.0 & 15.2 & 18.4 \\
\hline Dy & 0.8 & 0.8 & 0.8 \\
\hline $\mathrm{Fe}$ & 246.7 & 383 & 379 \\
\hline Gd & $<1$ & (a) & (a) \\
\hline K & 5.0 & 15 & 10 \\
\hline La & 0.7 & (.6) & $(.3)$ \\
\hline Li & 0.2 & (a) & $(.5)$ \\
\hline $\mathrm{Mg}$ & 8.6 & 19.0 & 19.9 \\
\hline $\mathrm{Mn}$ & 11.4 & 17.4 & 17.6 \\
\hline Mo & 1.2 & (a) & (a) \\
\hline $\mathrm{Na}$ & 20.6 & 40 & 46 \\
\hline Nd & 1.3 & $(2.1)$ & $(1.4)$ \\
\hline $\mathrm{Ni}$ & 41.4 & 64 & 64 \\
\hline Rh & 14.0 & (a) & (a) \\
\hline $\mathrm{Ru}$ & 4.2 & (a) & (a) \\
\hline Si & 16.5 & 30.9 & 52.0 \\
\hline$S r$ & 0.2 & $(.35)$ & $(.35)$ \\
\hline Te & (a) & (a) & (a) \\
\hline$T i$ & 17.4 & 26.7 & 27.3 \\
\hline $\mathrm{Zn}$ & 3.6 & 8.05 & 8.40 \\
\hline $\mathrm{Zr}$ & 3.9 & 6.20 & 6.10 \\
\hline
\end{tabular}

(a) Element not detected.

Values given in parentheses are approaching detection limit. 


\section{APPENDIX $F$}

CHEMICAL ANALYSIS DATA OF THE REFLECTOR WATER SAMPLES 


\section{APPENDIX $F$}

\section{CHEMICAL ANALYSIS DATA OF THE REFLECTOR WATER SAMPLES}

The sample for experiment 106 also covers experiment 106R. The sample for experiment 110 also covers experiment 110R. Reflector water analysis for experiment 117 was not performed; the data would be similar to other experiments. 
TABLE F.1 Water Sample Analyses of the Reflector Water

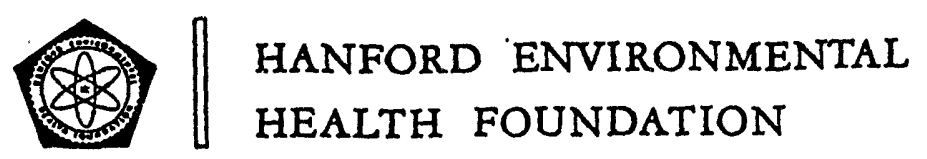

CO 12325

February 11, 1988

Pacific Northwest Laboratory

209-E Building, 200-E Area

Attn: R. C. Lloyd

WATER SAMPLES ANALYSES

The results of the analyses of the seven water samples received January 6 , 1988, are attached. Analyses were done in accordance with Standard Methods for the Analysis of Water and Wastewater, $16 \mathrm{th} \mathrm{ed}$.

If there are questions concerning this report, please contact us.

Pathenman

P. A. Thurman

Environmental Health Sciences

jt

Attach. 


\section{TABLE F.1 (Contd)}

\begin{tabular}{|c|c|c|c|c|c|c|c|}
\hline Parameter & $\begin{array}{l}\text { Exp.106, } \\
107.108\end{array}$ & Exp. E & Exo. 111 & ${ }_{112 .}^{\text {Exp }}$ & Exp. 114 & Exo. 115 & Exp.116 \\
\hline pH & 7.0 & 7.0 & 7.5 & 7.2 & 7.3 & 7.1 & 7.4 \\
\hline Total alkalinity $(\mathrm{mg} / \mathrm{L})$ & 55 & 55 & 56 & 56 & 54 & 57 & 56 \\
\hline $\mathrm{HCO}_{3}$ alkal inity (as $\left.\mathrm{CaCO}_{3}\right)(\mathrm{mg} / \mathrm{L})$ & 50 & 50 & 56 & 52 & 50 & 52 & 51 \\
\hline $\mathrm{CO}_{3}$ alkalinity (as $\mathrm{CaCO}_{3}$ ) (mg/L) & $<0.5$ & $<0.5$ & $<0.5$ & $<0.5$ & $<0.5$ & $<0.5$ & $<0.5$ \\
\hline Total dissolved solids (mg/L) & 86 & 85 & 89 & 79 & 76 & 101 & 105 \\
\hline Fluoride $(\mathrm{mg} / \mathrm{l})$ & $<0.2$ & $<0.2$ & $<0.2$ & $<0.2$ & $<0.2$ & $<0.2$ & $<0.2$ \\
\hline Chloride (mg/L) & 0.91 & 0.91 & 0.92 & 0.97 & 0.98 & 0.95 & 0.94 \\
\hline Nitrate (as N) (mg/L) & $<0.05$ & $<0.05$ & .088 & $<0.05$ & $<0.05$ & $<0.05$ & $<0.05$ \\
\hline Sulfate $(m g / L)$ & 10.6 & 10.7 & 10.7 & 10.7 & 11.7 & 11.5 & 10.5 \\
\hline Cadmium (mg/L & $<0.0005$ & $\$ 0.0005$ & $<0.0005$ & $<0.0005$ & $<0.0005$ & $<0.0005$ & $<0.0005$ \\
\hline Copper $(\mathrm{mg} / \mathrm{L})$ & $<0.05$ & $<0.05$ & $<0.05$ & $<0.05$ & $<0.05$ & $<0.05$ & $<0.05$ \\
\hline Chromium (mg/L) & $<0.005$ & $<0.005$ & $<0.005$ & $<0.005$ & $<0.005$ & $<0.005$ & $<0.005$ \\
\hline Iron $(m g / L)$ & $<0.03$ & $<0.03$ & $<0.03$ & $<0.03$ & $<0.03$ & $<0.03$ & $<0.03$ \\
\hline Lead $(\mathrm{mg} / \mathrm{L})$ & $<0.005$ & $<0.005$ & $<0.005$ & $<0.005$ & $<0.005$ & $<0.005$ & $<0.005$ \\
\hline Manganese $(m g / L)$ & $<0.01$ & $<0.01$ & $<0.01$ & $<0.01$ & $<0.01$ & $<0.01$ & $<0.01$ \\
\hline $\operatorname{Zine}(\mathrm{mg} / \mathrm{L})$ & 0.08 & 0.06 & 0.08 & 0.07 & 0.42 & 0.38 & 0.03 \\
\hline
\end{tabular}




\section{DISTRIBUTION}

No. of

Copies

\section{OFFSITE}

D. E. Balley, Director

Division of Fuels \& Reprocessing

U. S. Department of Energy

NE-551

Washington, DC 20545

M. J. Haire*

Oak Ridge National Laboratory

Martin Marietta Energy Systems, Inc.

Building 7601

P. 0. Box $X$

Oak Ridge, TN 37831-6305
A. D. Blakeman
W. D. Burch (3)
B. G. Eads
M. J. Feldman
W. S. Groenier
M. J. Haire (29)
C. M. Hopper
R. C. Kryter
S. A. Meacham
J. T. Mihalczo
L. C. Oakes
R. T. Primm, III
G. E. Ragan
C. W. Ricker
G. R. Smolen (2)
J. G. Stradley (5)
J. T. Thomas
R. M. Westfall
G. E. Whitesides
ORNL Patent Section
ORNL FRD Publications (2)
ORNL-RC
ORNL Records (2)
*28 copies to be delivered to DOE Technical Information
Center by M. J. Haire, and distribution made by OSTI per Distribution List S526.

No. of

Copies

F. P. Baranowski

657 Fairfax Way

Williamsburg VA 23185

M. J. Ohanian, Associate Dean for Research

College of Engineering

University of Florida

300 Well Hall

Gainesville, FL 32611

M. J. Rohr, Program Manager

Consolidated Fuel Reprocessing Program

Energy Programs Division

Energy Technology Branch

Oak Ridge, TN 37831-6305

Office of Assistant Manager Energy Research and Development

DOE-ORO

Oak Ridge, TN 37831-6305 
No. of

Copies

ONSITE

3 DOE Richland Operations Office

R. B. Goranson

D. K. Jones

J. J. Sutey

24 Pacific Northwest Laboratory

S. R. Bierman

E. D. Clayton

R. J. Hall

D. F. Newman

R. C. Lloyd (10)

L. N. Terry (CML RC) (2)

H. H. Van Tuyl

Publishing Coordination

Technical Report Files (5) 


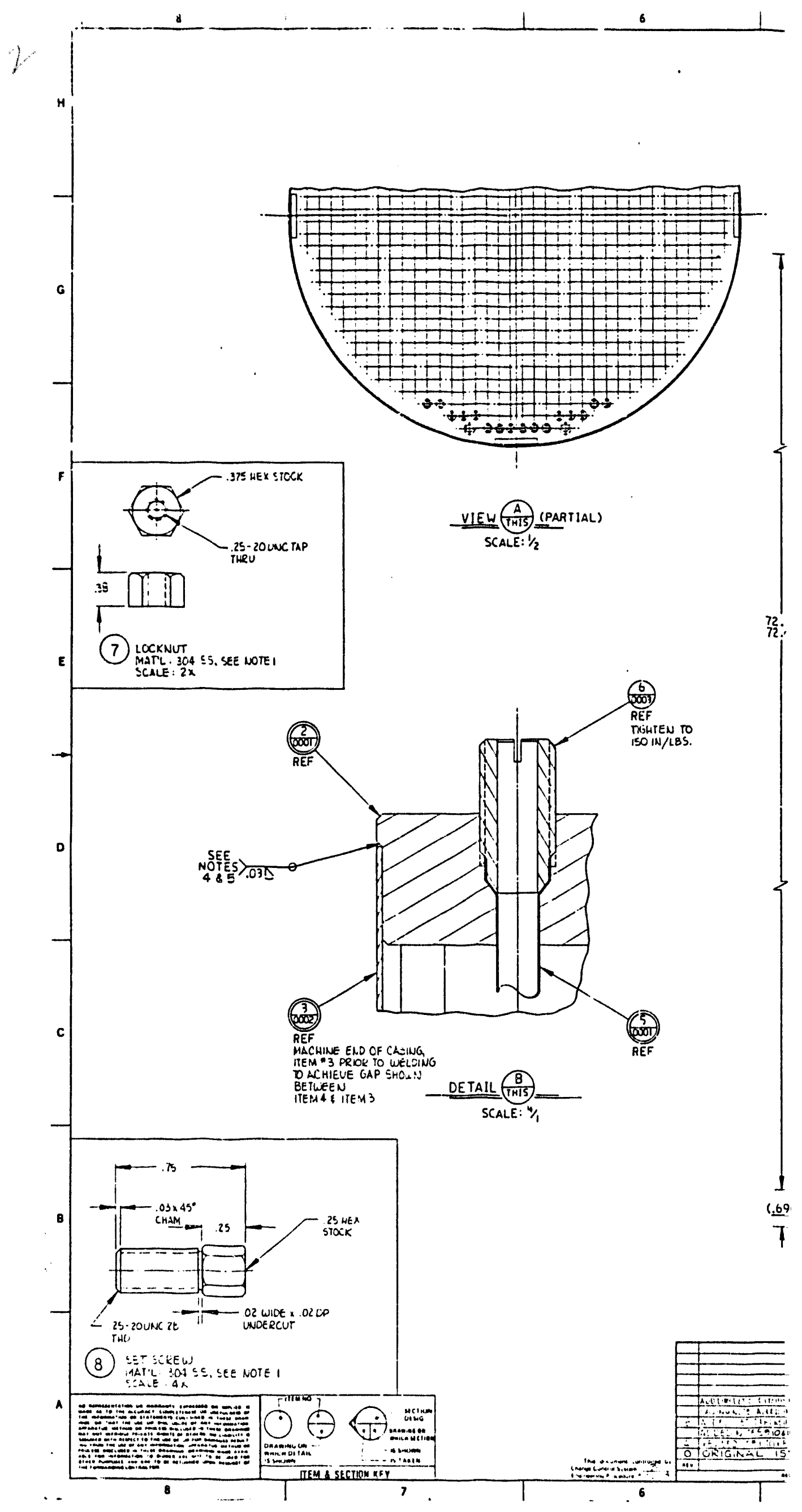




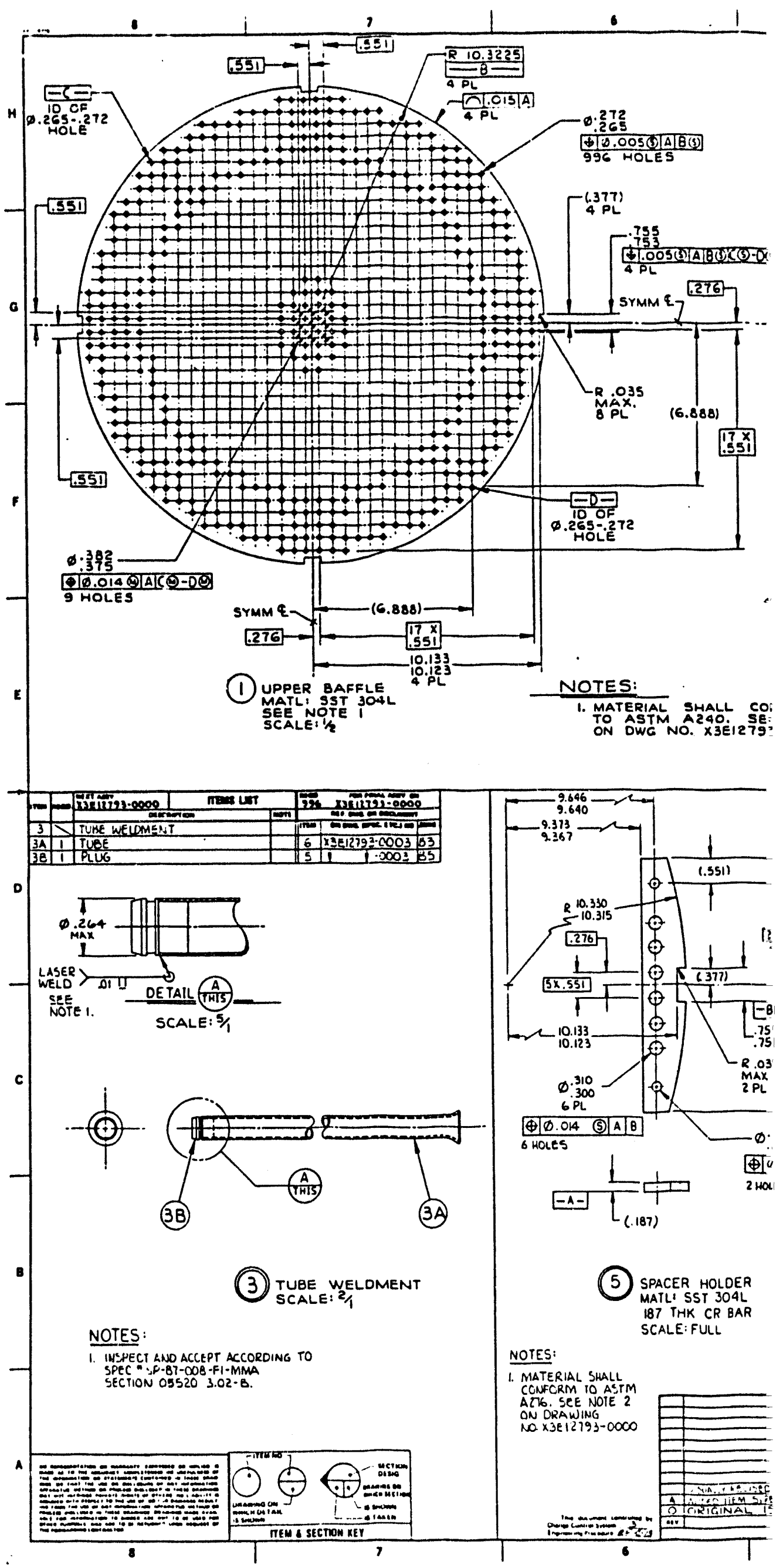




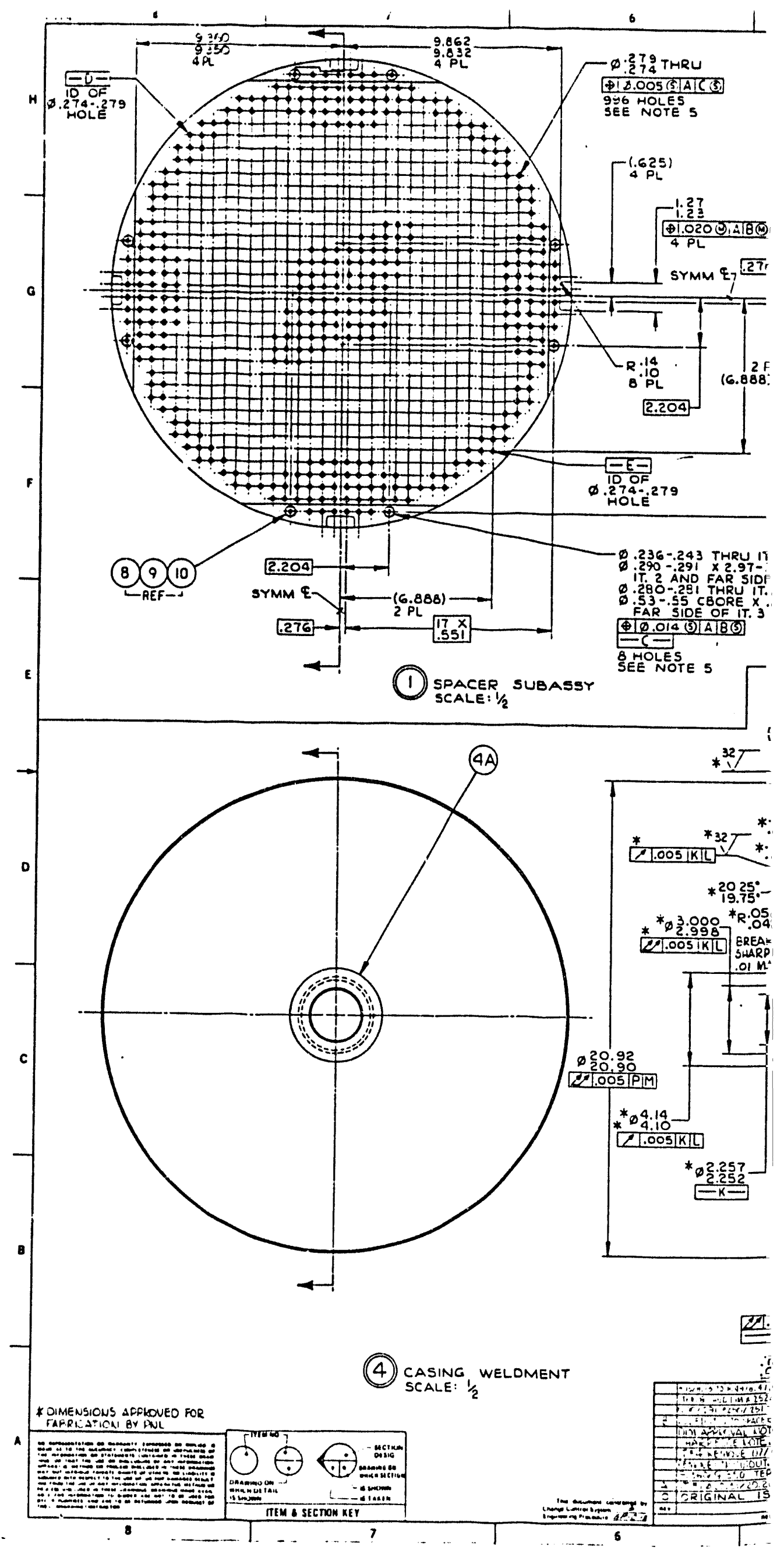




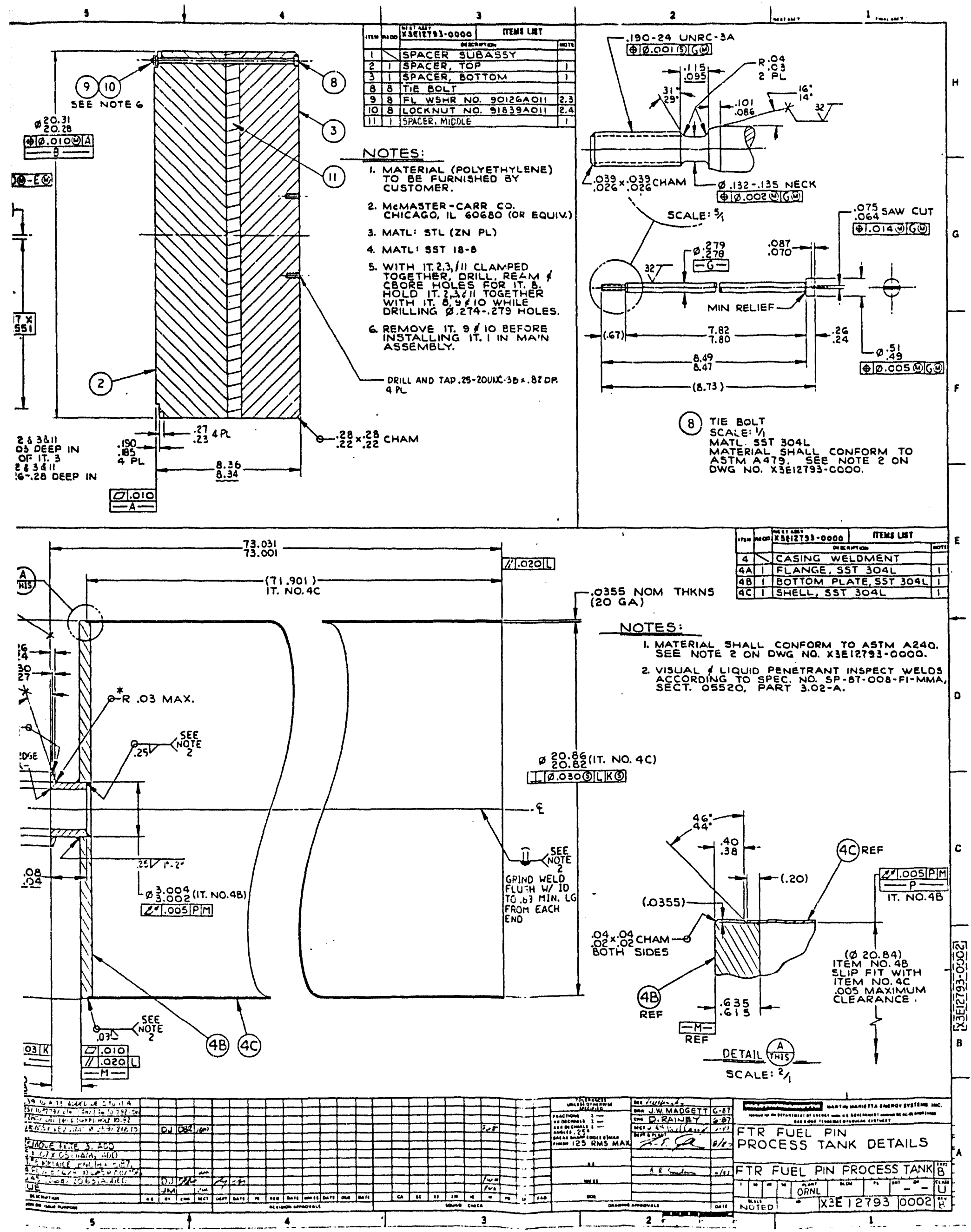

B. 3 


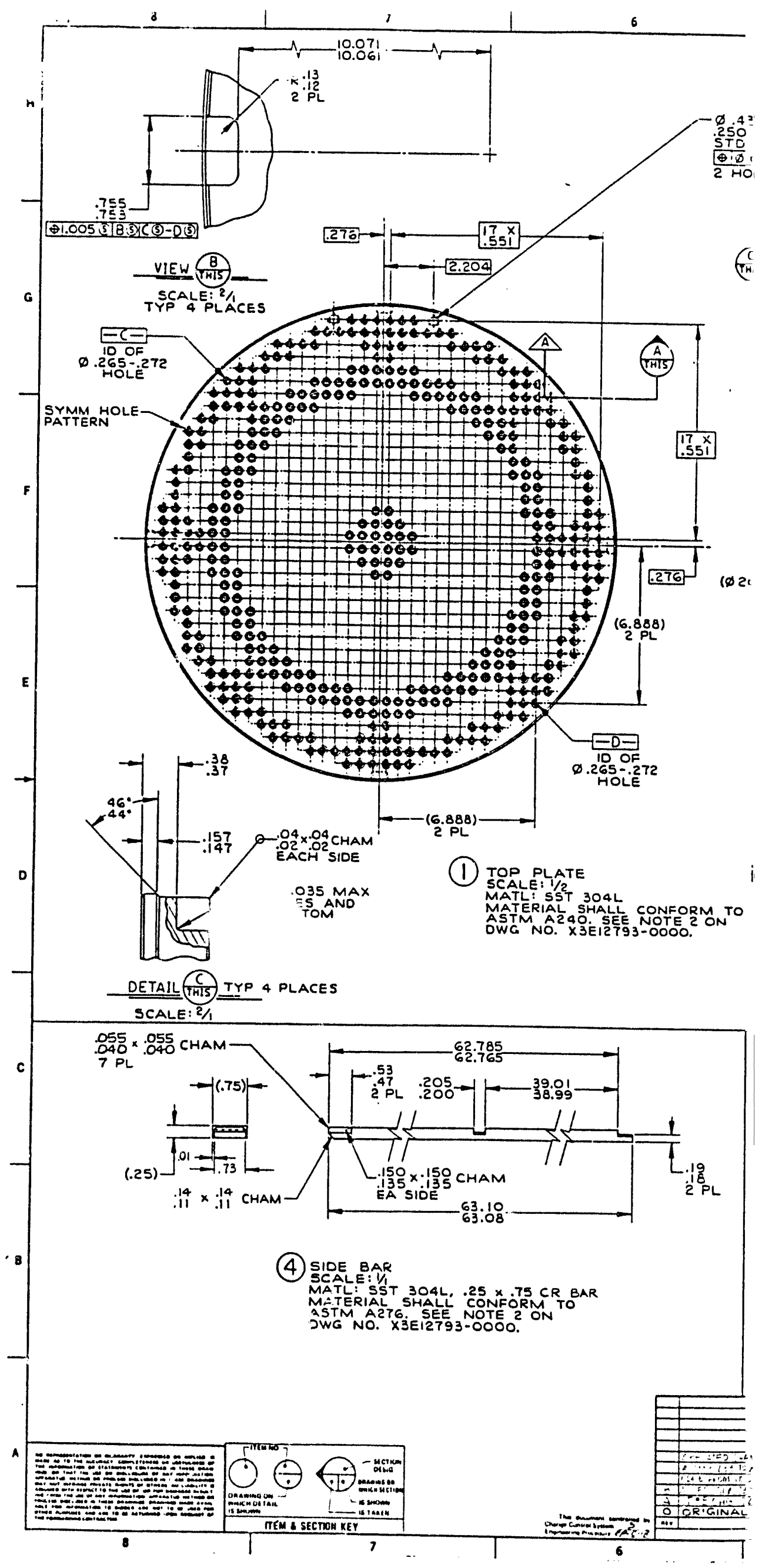




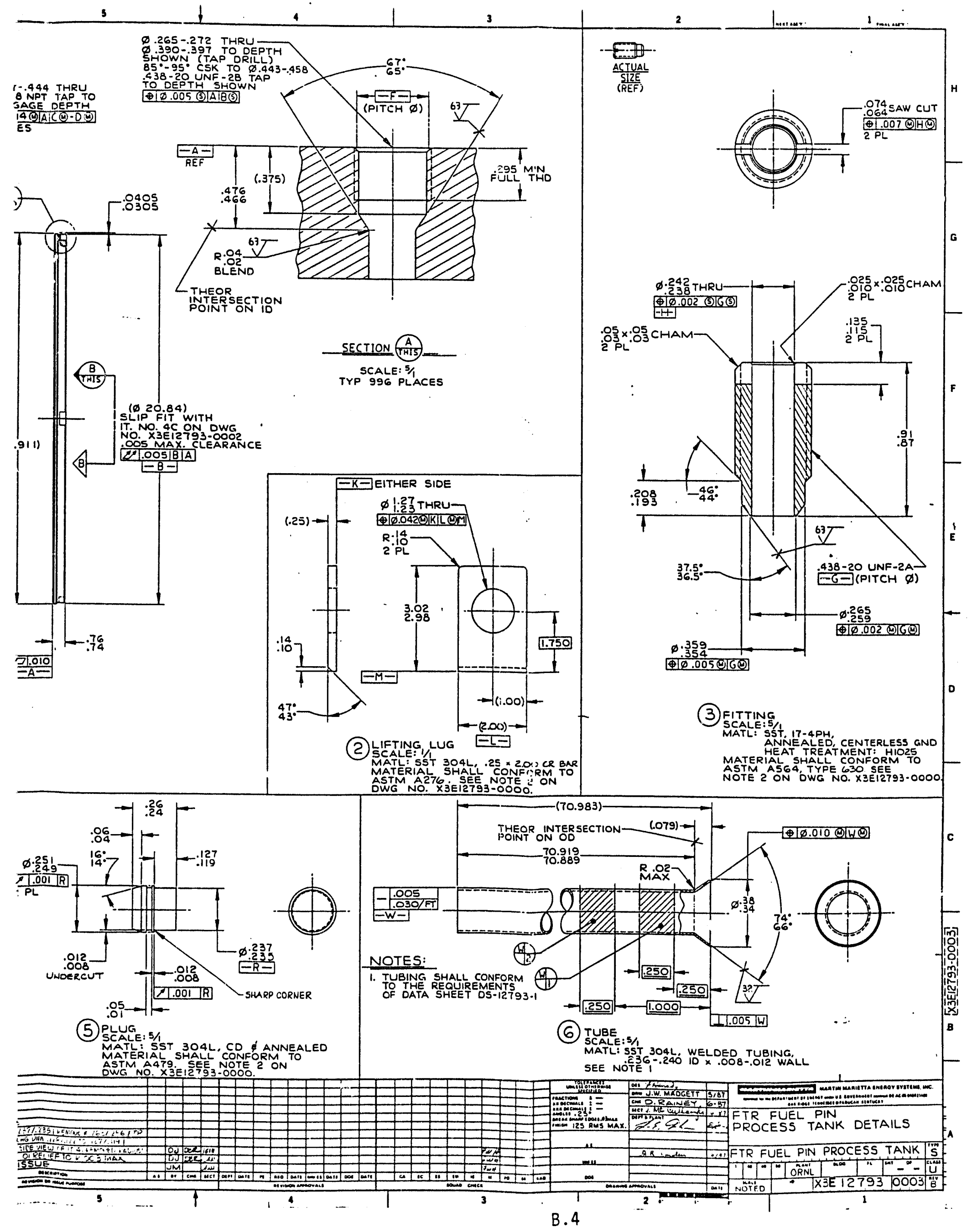



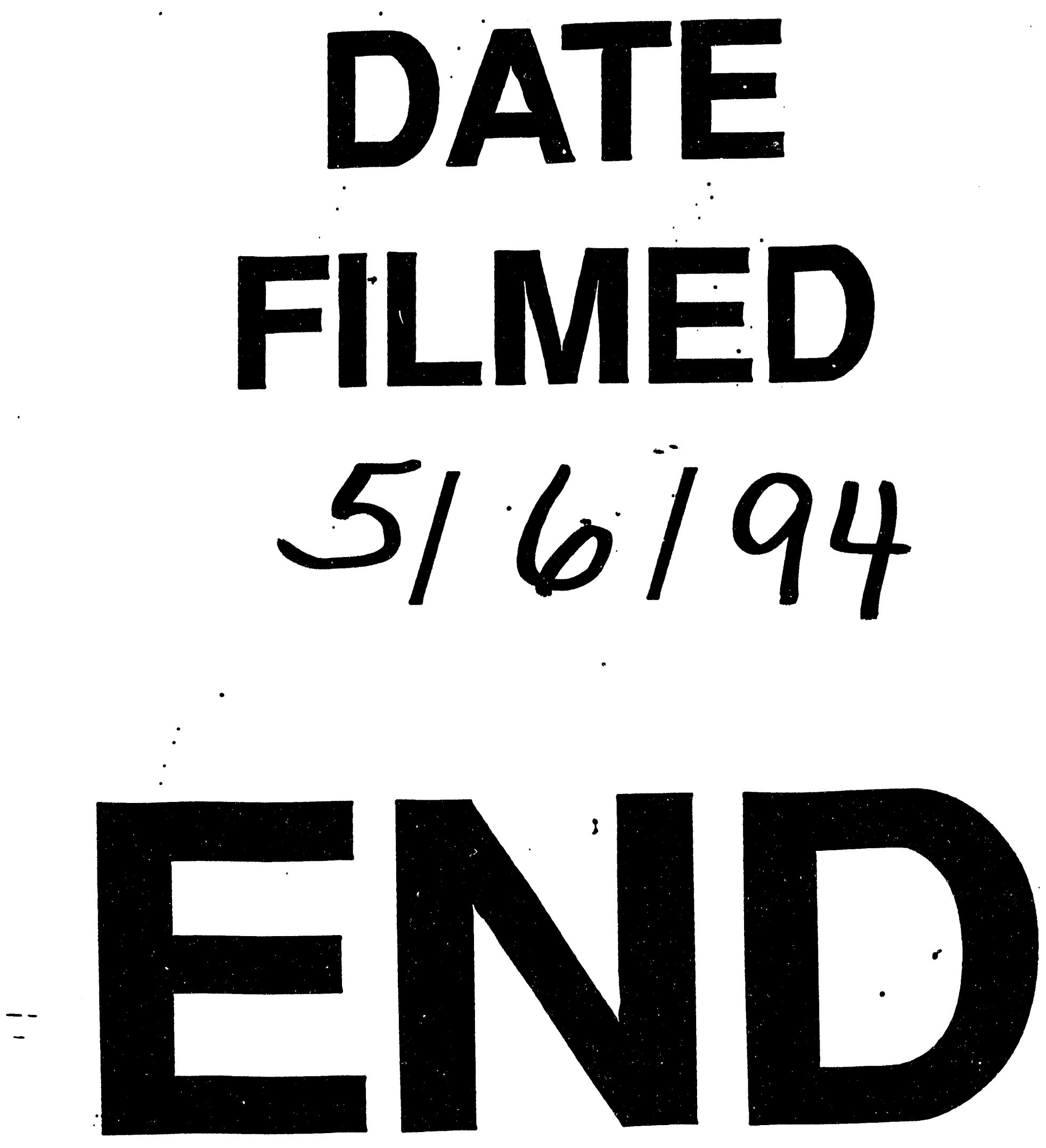
